Historic, Archive Document

Do not assume content reflects current scientific knowledge, policies, or practices. 


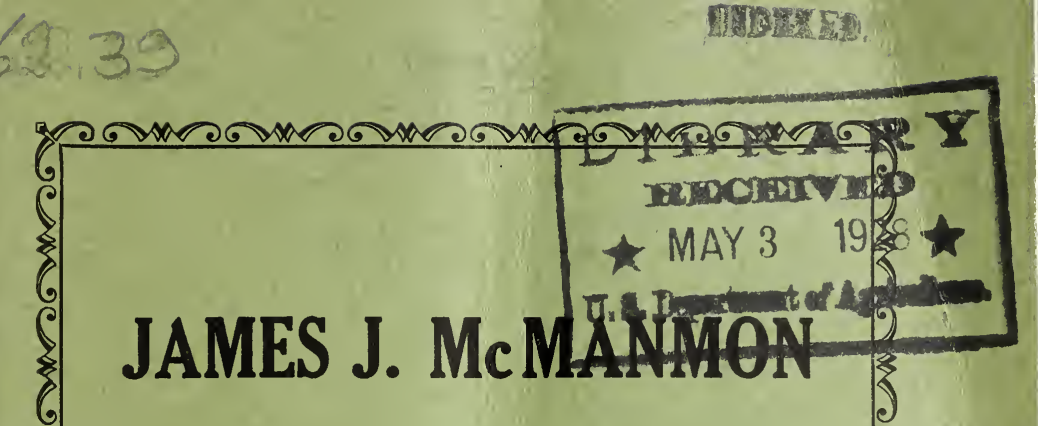

Florist, Nurseryman and Landscape Architect

Established 1895

DRACUT, MASS.

P. O. Box 794, Lowell, Mass. Telephone 6670

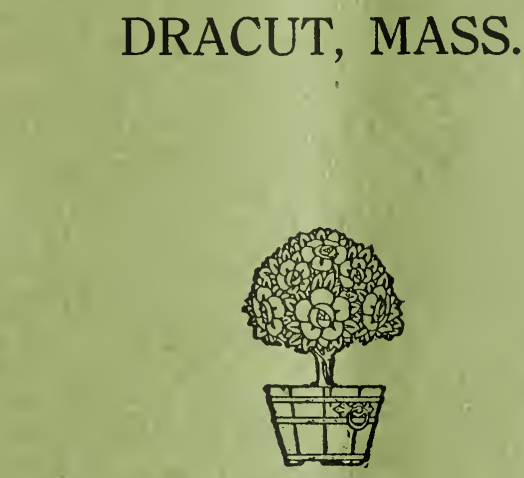




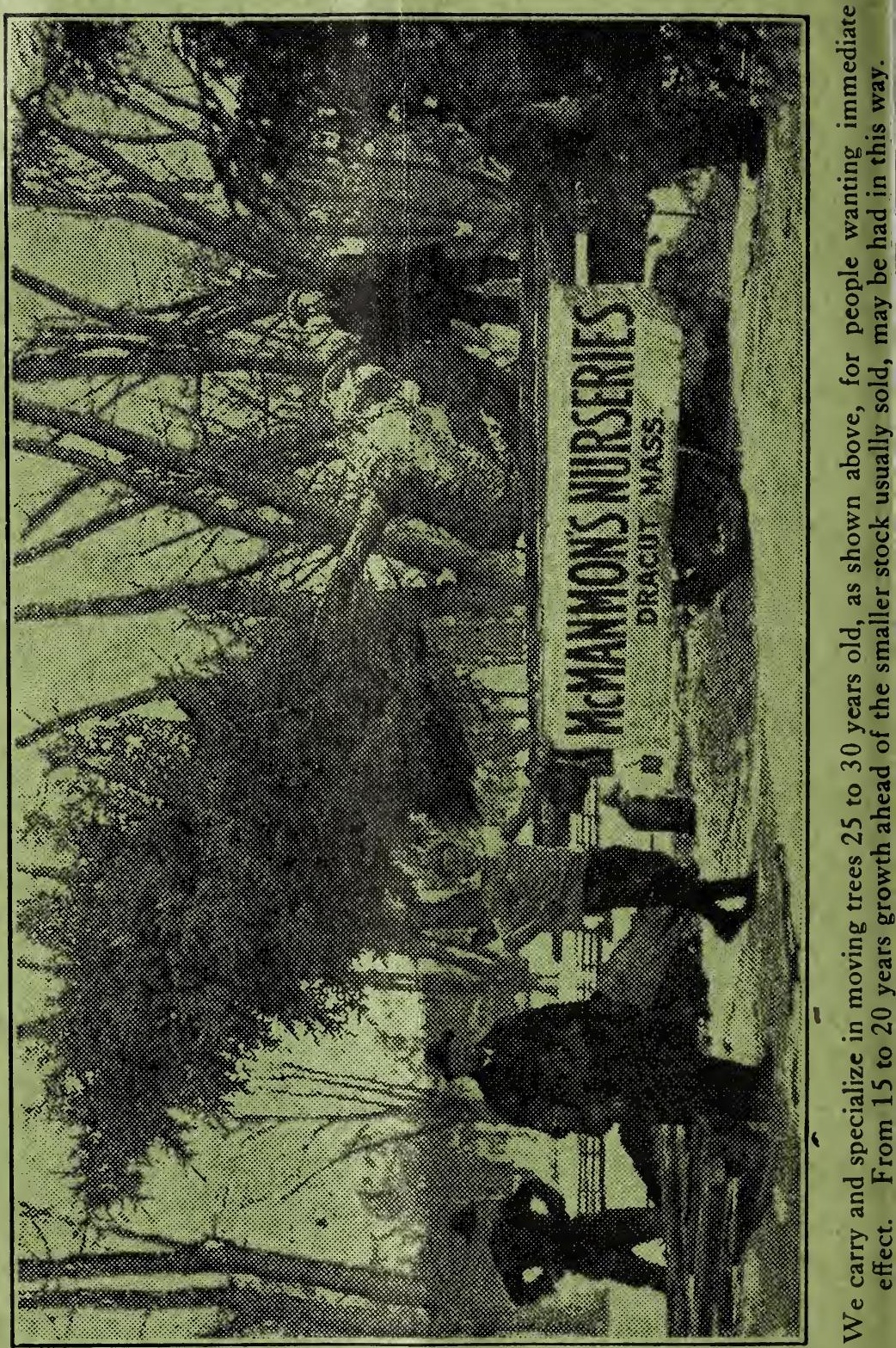




\section{Information}

Location of Nurseries:-On Lowell and Lawrence Boulevard, two miles from Lowell, 28 miles north of Boston, three miles from New Hampshire line.

We carry only Nursery Stock that will live in this climate, and when you receive stock grown here it will generally give satisfaction.

Purchasers should plainly state by what route their goods are to be conveyed. Otherwise we will forward them by the best in our opinion; but we will not be responsible in any way for delays or damage in transit, or loss in after-cultivation.

Automobile Delivery:-Orders of considerable size we can deliver by automobile trucks within a radius of fifty miles. Stock so shipped will arrive quickly and in as perfect condition as when it leaves the nursery. Cartage charges will depend on the size of the load and distance to be hauled.

Any errors committed by us will be cheerfully rectified if notice is given immediately.

Notice:-While we exercise the greatest care possible in having our stock true to name and free from disease, we give no warranty, express or implied, as to description, quality, productiveness, or any other matter of any Nursery Stock, Seeds, Bulbs or Plants we sell, and will not be in any way responsible for the crop. If the purchaser does not accept these goods on these terms, he must return them at once, and all payments therefor will be refunded.

Any shortage, error or overcharge must be reported within five days of receipt of goods.

No complaints will be considered that are not made within ten days after receipt of stock.

We carry larger trees than are found in most Nurseries. We make a specialty of moving Evergreen trees 25 to 35 years old in winter time in a frozen condition. We move them with perfect success. We prepare them before the ground freezes and lift them out with a ball of earth from one ton to five tons with our modern machinery and transfer them to your grounds in perfect condition. 


\section{ORNAMENTAL DEPARTMENT}

We carry larger sizes of some varieties than those listed. Prices furnished on application.

\section{DECIDUOUS TREES}

ICER PLATANOIDES

Norway Maple

$\begin{array}{rrrrr}6 & & \text { Each } & \text { Per } 10 & \text { Per } 100 \\ 8 \text { to } 8 \mathrm{ft} . & \$ 2.50 & \$ 22.50 & \\ 10 \text { to } 10 \mathrm{ft} . & 3.00 & 28.00 & \\ 14 \text { to } 18 \mathrm{ft} . & 6.50 \text { to } 20.00 & \text { Each } & \end{array}$

A. PLATANOIDES SCHWEDLERI Schwedler's Purple Maple
5 to $6 \mathrm{ft}$.
2.50
6 to $8 \mathrm{ft}$.
3.50

A. PALMATUM

12 to 18 inches

2.00

Japanese Maple

17.50

$\$ 150.00$

A. PALMATUM VAR. ATROPURPUREUM
12 to 18 inches
2.50
Blood-leaved Japan Maple
22.50

A. SACCHARINUM (DASYCARPUM)

Silver Maple

One of the most rapid growing trees for street or lawn planting. Desirable where immediate effects are required.
6 to $8 \mathrm{ft}$.
1.00
8 to $10 \mathrm{ft}$.
1.50
10 to $12 \mathrm{ft}$.
12 to $14 \mathrm{ft}$.
2.25
3.00
9.00
14.00
20.00
25.00
75.00
130.00
180.00

\section{A. SACCHARINUM VAR. WEIRI}

Weir's Cut-leaved Maple

A graceful drooping tree suitable for the lawn. Very rapid growing tree.
6 to $8 \mathrm{ft}$.
1.50
13.50
120.00
8 to $10 \mathrm{ft}$.
2.00
10 to $12 \mathrm{ft}$.
3.00

A. SACCHARUM

6 to $8 \mathrm{ft}$.
8 to $10 \mathrm{ft}$.
10 to $12 \mathrm{ft}$.

$\begin{array}{rrr}4 \text { to } 6 \mathrm{ft} . & 1.50 \\ 6 \text { to } 8 \mathrm{ft} . & 2.50 \\ 8 \text { to } 10 \mathrm{ft} . & 3.00 \\ 12 \text { to } 14 \mathrm{ft} . & 5.00\end{array}$

Sugar or Rock Maple

17.50

22.50

Common Horse Chestnut 
A. CARNEA (RUBICUNDA) Red-Flowered Horse Chestnut

$$
3 \text { to } 4 \mathrm{ft} \text {. }
$$

Each

Per 10 Per 100

2.00

ASH See Fraxinus

BETULA ALBA

White Birch

4 to $5 \mathrm{ft}$.

B. ALBA LACINIATA

$\begin{array}{llll}3 & \text { to } & 4 & \mathrm{ft} \\ 4 & \text { to } & 5 & \mathrm{ft} \\ 5 & \text { to } & 6 & \mathrm{ft}\end{array}$

B. ALBA FESTIGIATA

$$
3 \text { to } 4 \mathrm{ft} \text {. }
$$

B. LUTEA

$$
\begin{aligned}
& 4 \text { to } 6 \mathrm{ft} \text {. } \\
& 6 \text { to } 8 \mathrm{ft} \text {. }
\end{aligned}
$$

B. PAPYRIFERA

$$
\begin{aligned}
& 4 \text { to } 6 \mathrm{ft} \text {. } \\
& 6 \text { to } \\
& 8 \mathrm{ft} .
\end{aligned}
$$

CATALPA BUNGEII

\section{1 year heads}

2 year heads

C. SPECIOSA

$\begin{array}{rr}6 \text { to } 8 \mathrm{ft} . & 1.25 \\ 8 \text { to } 10 \mathrm{ft} . & 1.50 \\ 10 \text { to } 12 \mathrm{ft} . & 2.00\end{array}$

CLADRASTIS LUTEA (TINCTORIA)
6 to $8 \mathrm{ft}$.
8 to $10 \mathrm{ft}$.
2.50
3.50

CORNUS FLORIDA

2 to $3 \mathrm{ft}$.

3 to $4 \mathrm{ft}$.

4 to $5 \mathrm{ft}$.

C. FI.ORIDA RUBRA
18 to $24 \mathrm{in}$.
2 to $3 \mathrm{ft}$.
3 to $4 \mathrm{ft}$.
1.00
1.50
2.50
2.50
3.50
5.00

Cut-leaved Weeping Birch

$\begin{array}{ll}2.00 & 15.00 \\ 2.50 & 17.50 \\ 3.50 & \end{array}$

Pyramid White Birch

Yellow Birch

1.25

1.50

1.50

1.75

2.00

3.00

Canoe or Paper Birch

12.00

15.00

Umbrella Catalpa

White Flowered Dogwood

Yellow Wood

CRATAEGUS OXYCANTHA WHITE

White Hawthorn
3 to $4 \mathrm{ft}$.
1.50
2.00

4 to $5 \mathrm{ft}$.

C. OXYCANTHA PAUL'S SCARLET

3 to $4 \mathrm{ft}$.
4 to $5 \mathrm{ft}$.

1.50

2.00

C. OXYCANTHA PINK

3 to $4 \mathrm{ft}$.

4 to $5 \mathrm{ft}$.

2.00
9.00

13.50

80.00

120.00

Pink Flowered Dogwood

14.00

18.00

130.00

160.00

Scarlet Hawthorn 14.00

18.00

130.00

140.00

Pink Hawthorn 
CRAB, FLOWERING See Malus DOGWOOD See Cornus Florida GINKGO BILOBA OR SALISBURIA Maiden Hair Tree

$\begin{array}{rrr} & & \text { Each } \\ 6 \text { to } 8 \mathrm{ft} & 2.50 \\ 8 \text { to } 10 \mathrm{ft} & 3.50 \\ 10 \text { to } 12 \mathrm{ft} & 4.50\end{array}$

KOELRUTERIA PANICULATA

$\begin{array}{rrr}6 \text { to } 7 \mathrm{ft} . & \mathbf{1 . 5 0} \\ 8 \text { to } 10 \mathrm{ft} . & 2.50\end{array}$

Per 10 Per 100

LARIX EUROPEA
6 to $8 \mathrm{ft}$
2.00

L. LEPTOLEPIS

6 to $8 \mathrm{ft}$. 2.00

\section{LINDEN See Tilia}

LIRIODENDRON TULIPIFERA

Tulip Tree
5 to $6 \mathrm{ft}$.
6 to $8 \mathrm{ft}$.
1.00
1.50

MALUS

$\begin{array}{llll}2 & \text { to } & 3 \mathrm{ft} . \\ 3 & \text { to } & 4 & \mathrm{ft} \\ 4 & \text { to } & 5 & \mathrm{ft}\end{array}$

1.00

1.25

2.00

ATROSANGUINEA

Carmine Crab

Much like floribunda, but with brilliant carmine flowers.

BACCATA

Siberian Crab

Tall narrow tree, small white flowers and tiny orange or scarlet fruit.

\section{FLORIBUNDA}

Japanese Flowering Crab

Bright pink flower huds, white flowers. Small yellowish fruit, much liked by hirds.

\section{HALLIANA PARKMANI}

Parkman Crab

Bright rose-red, double flowers hang on long slender stems.

IOENSIS PLENA

Bechtel Crab

Double pink flowers like small clustered roses.

NIEDZWETZKYANA

Redvein Crab

Early. Remarkable for the red color of flowers, branches, leaves and fruit.

SCHEIDECKERI

Scheidecker Crab

Early. Small tree of pyramidal habit with small bright rosecolored flowers in great profusion.

MAIDENHAIR TREE See Ginkgo

MAPLE See Acer

MOUNTAIN ASH See Sorbus 
We carry larger sizes of some varieties than those listed. Prices furnished on application.

MORUS ALBA

$\begin{array}{llll} & \text { Each } & \text { Per } 10 \text { Per } 100 \\ 4 \text { to } 6 \mathrm{ft} . & 1.00 & & \\ 6 \text { to } 8 \mathrm{ft} & 1.75 & & \end{array}$

White Mulberry

M. TARTARICA VAR. PENDULA Tea's Weeping Mulberry One year heals $\quad 3.00$

OAK See Quercus

POPLAR ALBA

$\begin{array}{rrrr}6 & \text { to } 8 \mathrm{ft} . & .75 & 6.00 \\ 8 \text { to } 10 \mathrm{ft} . & 1.25 & 10.00\end{array}$

P. DELTOIDES MONILIFERA

Carolina Poplar Tall spreading tree. Invaluable for quick shade or screen.
8 to $10 \mathrm{ft}$.
1.00
10 to $12 \mathrm{ft}$.
1.35
8.00
60.00
12 to $14 \mathrm{ft}$.
1.75
10.00
13.50
75.00
Lombardy Poplar

P. NIGRA ITALICA

$\Lambda$ very rapid growing tree. Useful as a screen for hiding undesirable objects or buildings. Our trees are grown with branches from the ground up.

$\begin{array}{rrrr}6 \text { to } 8 \mathrm{ft} . & .75 & 6.00 & 50.00 \\ 8 \text { to } 10 \mathrm{ft} . & 1.00 & 8.00 & 65.00 \\ 10 \text { to } 12 \mathrm{ft} . & 1.25 & 10.00 & 90.00 \\ 12 \text { to } 14 \mathrm{ft} . & 2.00 & 18.00 & \end{array}$

P. SIMONII

6 to $8 \mathrm{ft}$.
8 to $10 \mathrm{ft}$.

PRUNUS PISSARDI

4 to $5 \mathrm{ft}$.

QUERCUS COCCINEA

$$
8 \text { to } 10 \mathrm{ft} \text {. }
$$

1.25

1.00

Q. PALUSTRIS

$$
\begin{aligned}
& 5 \text { to } 6 \mathrm{ft} \text {. } \\
& 6 \text { to } 8 \mathrm{ft} \text {. }
\end{aligned}
$$

Q. RUBRA

$$
6 \text { to } 8 \mathrm{ft} \text {. }
$$

3.00

3.00

SALISBURIA See Ginkgo SALIX BLANDA
6 to $8 \mathrm{ft}$.
8 to $10 \mathrm{ft}$.

Cork Barked

8.50

11.00

Purple leaved Plum.

$$
\text { Scarlet Oak }
$$

Pin Oak

15.00

25.00

Red Oak

24.00 
We carry larger sizes of some varieties than those listed. Prices furnished on application.

S. ELEGANTISSIMA

$\begin{array}{rrrr}6 & \text { to } & 8 \mathrm{ft} . \\ 8 & \text { to } 10 \mathrm{ft} .\end{array}$

S. PENTANDRA
6 to $8 \mathrm{ft}$
8 to $10 \mathrm{ft}$.

S. VITELLINA AUREA

$$
\begin{array}{rlrr}
5 & \text { to } & 6 \mathrm{ft} . \\
6 & \text { to } & 8 \mathrm{ft} . \\
8 & \text { to } 10 & \mathrm{ft} .
\end{array}
$$

SORBUS AUCUPARIA

$$
\begin{array}{rrrr}
5 & \text { to } & 6 & \mathrm{ft} . \\
6 & \text { to } & 8 \mathrm{ft} . \\
8 & \text { to } & 10 & \mathrm{ft}
\end{array}
$$

3.00

TILIA PLATYPHYLLOS

6 to $8 \mathrm{ft}$.

T. VULGARIS

$$
6 \text { to } 8 \mathrm{ft} \text {. }
$$

TULIP TREE See Liriodendron ULMUS AMERICANA

$$
8 \text { to } 10 \mathrm{ft} \text {. }
$$$$
10 \text { to } 12 \mathrm{ft}
$$

12 to $14 \mathrm{ft}$.

WILLOW See Salix
Thurlow's Willow Per 10 Per 100 $12.00 \quad 100.00$ 13.50

Laurel-leaved Willow

$$
\begin{array}{rr}
8.50 & 75.00 \\
12.50 &
\end{array}
$$

Golden Bark Willow 6.00

7.50

11.00

Mountain Ash 11.00 16.00

Broad-leaf Linden European Linden American Elm 20.00 27.50 


\section{EVERGREEN TREES}

We carry larger sizes of some varieties than those listed. Prices furnished on application.

ABIES BRACHYPHYLLA

\section{8 to 24 in.}

ABIES C.ONCOLOR

$1 \frac{1}{2}$ to $2 \mathrm{ft}$.

2 to $2 \frac{1}{2} \mathrm{ft}$.

$2 \frac{1}{2}$ to $3 \mathrm{ft}$.

3 to $4 \mathrm{ft}$.

4 to $5 \mathrm{ft}$.

5 to $6 \mathrm{ft}$.
Nikka or Japanese Fir Per 10 Per 100

Each

3.00

4.00

6.00

千.50

8.50

10.00

12.50

Silver or White Fir

ARBOR VITAE See Thuya

FIR See Abies

HEMLOCK See Tsuga

JUNIPERUS CHINENSIS

$\begin{array}{ll}2 \text { to } 3 \mathrm{ft} . & 4.50 \\ 3 \text { to } 4 \mathrm{ft} . & 6.00 \\ 4 \text { to } 5 \mathrm{ft} . & 7.50\end{array}$

Chinese Juniper

J. CHINENSIS ALBOVARIEGATA

$\begin{array}{ccc}18 \text { to } 24 \text { in. } & 3.50 & 30.00 \\ 2 \text { to } 21 / 2 \mathrm{ft} . & 5.00 & 45.00 \\ 21 / 2 \text { to } 3 \mathrm{ft} . & 6.00 & 54.00\end{array}$

White Tipped Chinese Juniper $3.50 \quad 30.00$

6.00

J. CHINENSIS VAR. PFITZERIANA

1 to $11 / 2 \mathrm{ft}$.

2.50

$11 / 2$ to $2 \mathrm{ft}$.

3.50

2 to $21 / 2 \mathrm{ft}$.

$21 / 2$ to $3 \mathrm{ft}$.

4.50

6.50

J. COMMUNIS

12 to $15 \mathrm{in}$.
15 to $18 \mathrm{in}$.
$1 \frac{1}{2}$ to $2 \mathrm{ft}$.
2 to $21 / 2 \mathrm{ft}$.

J. COMMUNIS VAR. AUREA

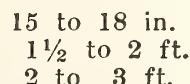

1.50

1.75

2.00

3.00

Golden Prostrate Juniper

2.00

3.00

4.00

$$
13.50
$$

16.50

18.00 27.00 18.00 25.00

J. COMMUNIS VAR. HIBERNICA

18 to $24 \mathrm{in}$.
2 to $3 \mathrm{ft}$.

1.75

2.50

J. COMMUNIS VAR. SUECICA

Pfitzer's Juniper 22.50

30.00

42.00

60.00

Prostrate Juniper

2 to $3 \mathrm{ft}$.

$\begin{array}{rr} & \text { Irish Juniper } \\ 16.00 & 150.00 \\ 22.50 & 200.00\end{array}$

Swedish Juniper 
J. EXCELSA VAR. STRICTA

Jirch

12 to 15 in. 15 to 18 in.

J. SABINA

3.00

12 to 15 in.
15 to 18 in.
18 to 24 in.

2.00

2.75

3.50

J. SABINA VAR. TAMERICIFOLIA 12 to $15 \mathrm{in.}$

2.00

J. VIRGINIANA

$\begin{array}{lr}2 \text { to } 3 \mathrm{ft} . & 3.00 \\ 3 \text { to } 4 \mathrm{ft} . & 4.50 \\ 4 \text { to } 5 \mathrm{ft} . & 6.50 \\ 5 \text { to } 6 \text { ft. } & 8.00 \\ 6 \text { to } 7 \mathrm{ft} . & 10.00\end{array}$

J. VIRGINIANA VAR. TRIPARTITA
18 to 24 in.
2 to $3 \mathrm{ft}$.
1.50
2.50

PICEA CANADENSIS

$$
\begin{aligned}
& 12 \text { to } 18 \mathrm{in} \text {. } \\
& 1 \frac{1 / 2}{10} 2 \mathrm{ft} \text {. } \\
& 2 \text { to } 3 \mathrm{ft} \text {. }
\end{aligned}
$$

1.00

1.25

2.00

P. ALBERTIANA

$$
12 \text { to } 18 \text { in. }
$$$$
2 \text { to } 2 \frac{1}{2} \mathrm{ft} \text {. }
$$

P. ENGLEMANII

$$
\begin{array}{r}
18 \text { to } 24 \mathrm{in} . \\
2 \text { to } 3 \mathrm{ft} .
\end{array}
$$

P. EXCELSA

$$
\begin{aligned}
& 12 \text { to } 18 \text { in. } \\
& 11 / 2 \text { to } 2 \mathrm{ft} \text {. } \\
& 2 \text { to } 3 \mathrm{ft} \text {. } \\
& 3 \text { to } 4 \mathrm{ft} .
\end{aligned}
$$

P. PUNGENS

$$
\begin{aligned}
& 12 \text { to } 18 \mathrm{in} \text {. } \\
& 1 \frac{1}{2} \text { to } 2 \mathrm{ft} \text {. } \\
& 2 \text { to } 3 \mathrm{ft} \text {. } \\
& 31 / 2 \mathrm{ft} . \\
& 4 \mathrm{ft} . \\
& 41 / 2 \mathrm{ft} \text {. } \\
& 5 \mathrm{ft} \text {. } \\
& 51 / 2 \mathrm{ft} . \\
& 6 \mathrm{ft} .
\end{aligned}
$$

2.00

3.00

2.00

350

1.00

1.25

2.50

4.00

2.00

3.00

5.00

7.50

11.00

12.50

14.00

15.00

16.00

P. PUNGENS GLAUCA

$\begin{array}{lr}12 \text { to } 18 \text { in. } & 4.00 \\ 11 / 2 \text { to } 2 \text { ft. } & 6.00 \\ 2 \text { to } 21 / 2 \mathrm{ft} . & 7.50 \\ 3 \mathrm{ft} . & 10.00 \\ 31 / 2 \mathrm{ft} & 12.50 \\ 4 \mathrm{ft} . & 15.00\end{array}$

Greek Juniper

Per 10 L'er 100

Savin Juniper

17.50

25.00

30.00

150.00

225.00

Red Cedar

Spreading Cedar

White Spruce

9.00

11.50

8.5 .00

100.00

Black Hill Spruce

Engleman's Spruce

$\begin{array}{rr}\text { Norway } & \text { Spruce } \\ 9.00 & 80.00 \\ 12.00 & 110.00 \\ 22.50 & \\ 37.50 & \end{array}$

Colorado Spruce

$1 \% .50$

$2 \pi .50$

45.00

ז0.00

150.00

250.00

400.00

600.00

Colorado Blue Spruce 
P. PUNGENS GLAUCA

$\begin{array}{ll} & \text { Each } \\ 4.1 / 2 \mathrm{ft} . & 15.75 \\ 5 \mathrm{ft} . & 16.50 \\ 51 / 2 \mathrm{ft} & 17.50 \\ 6 \mathrm{ft} . & 20.00 \\ 61 / 2 \mathrm{ft} . & 22.50\end{array}$

P. PUNGENS VAR. KOSTERIANA Prices on application.

PINUS AUSTRIACA

$$
2 \text { to } 3 \mathrm{ft} \text {. }
$$

P. DENSIFLORA

2 to $3 \mathrm{ft}$.
3 to $4 \mathrm{ft}$.
4 to 5
5 to $6 \mathrm{ft}$.

P. MONTANA VAR. MUGHUS

12 to 15 in. spread

15 to 18 in. spread

$1 \frac{1 / 2}{2}$ to $2 \mathrm{ft}$. spread

P. RESINOSA

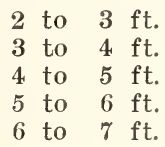

P. STROBUS

2 to $3 \mathrm{ft}$.
3 to $4 \mathrm{ft}$.
4 to 5
5 to 6
6 to 7
7 to 8
7 ft.

P. SYLVESTRIS

2 to $3 \mathrm{ft}$.

4 to $5 \mathrm{ft}$.

PSEUDOTSUGA DOUGLASII

$1 \frac{1}{2}$ to $2 \mathrm{ft}$.

2 to $3 \mathrm{ft}$.

3 to $4 \mathrm{ft}$.

RETINOSPORA FILIFERA

$$
\begin{aligned}
& 12 \text { to } 18 \mathrm{in} \text {. } \\
& 11 / 2 \text { to } 2 \mathrm{ft} \text {. } \\
& 2 \text { to } 3 \mathrm{ft} \text {. }
\end{aligned}
$$

R. PISIFERA

$$
\begin{aligned}
& 11 / 2 \text { to } 2 \mathrm{ft} \text {. } \\
& 2 \text { to } 3 \mathrm{ft} \text {. }
\end{aligned}
$$

R. PISIFERA VAR. AUREA

$1 \frac{1}{2}$ to $2 \mathrm{ft}$.

2 to $21 / 2 \mathrm{ft}$.

4.00

6.00

6.00

7.50

Colorado Blue Spruce

Per 10 Per 100

Koster's Blue Spruce

Austrian Pine

36.00

54.00

Japanese Red Pine

$\begin{array}{ll}3.00 & 25.00 \\ 4.50 & 40.00\end{array}$

$\begin{array}{ll}3.00 & 25.00 \\ 4.50 & 40.00\end{array}$

Mugho or Dwarf Mountain Pine

2.50

3.00

4.00

2.50

4.50

5.00

6.00

8.00

2.50

3.00

4.50

6.00

7.50

10.00

2.50

4.00

5.00

2.50

4.00

6.00

2.00

3.50

4.50

2.00

3.00

Golden Pea-fruited Cypress

Red Pine

22.50

42.50

200.00

White Pine

22.50

27.50

4.2 .50

54.00

70.00

Scotch Pine

22.50

37.50

Douglas Spruce 24.00

37.50

58.00

Thread-like Cypress

15.00

30.00

Pea-fruited Cypress 2.00

2.50 
R. PLUMOSA

$1 \frac{1}{2}$ to $2 \mathrm{ft}$.

R. PLUMOSA VAR. AUREA

$1 \frac{1}{2}$ to $2 \mathrm{ft}$.

TAXUS CANADENSIS

$$
\begin{aligned}
& 12 \text { to } 15 \mathrm{in} . \\
& 15 \text { to } 18 \mathrm{in.}
\end{aligned}
$$

T. CUSPIDATA

$$
\begin{aligned}
& 12 \text { to } 18 \mathrm{in} \text {. } \\
& 11 / 2 \text { to } 2 \mathrm{ft} \text {. } \\
& 2 \text { to } 2 \frac{1}{2} \mathrm{ft} \text {. }
\end{aligned}
$$

6.00

T. CUSPIDATA ERECTA

$$
\begin{aligned}
& 12 \text { to } 18 \text { in. } \\
& 18 \text { to } 24 \text { in. }
\end{aligned}
$$$$
2.00
$$

Each

2.00

2.00

T. CUSPIDATA NANA (Brevifolia)
3.00

4.00
3.00

4.00

6.00

12 to 15 in.

THUYA OCCIDENTALIS

$1 \frac{1}{2}$ to $2 \mathrm{ft}$.

1.50

2 to $2 \frac{1}{2} \mathrm{ft}$.

$2 \frac{1}{2}$ to $3 \mathrm{ft}$.

3 to $3 \frac{1}{2} \mathrm{ft}$.

$4 \mathrm{ft}$.

$41 / 2 \mathrm{ft}$.

$5 \mathrm{ft}$.

2.00

3.00

$+.00$

5.00

6.00

6.50

Plume-like Cypress Per 10 Per 100 17.50

Golden Plume Cypress 17.50

Canadian Yew 12.00 18.00 100.00

Japanese Yew

$\begin{array}{ll}24.00 & 210.00 \\ 36.00 & 330.00\end{array}$

Pyramid Jap. Yew

Spreading Japanese Yew 27.00 36.00 54.00

American Arbor Vitae 14.00 $18.50 \quad 175.00$ $27.50 \quad 240.00$ $37.50 \quad 350.00$ 45.00

T. OCCIDENTALIS VAR. AUREA Geo. Peabody Arbor Vitae

$\begin{array}{ll}15 \text { to } 18 \text { in. } & 1.50 \\ 11 / 2 \text { to } 2 \mathrm{ft} . & 2.00\end{array}$

T. OCCIDENTALIS VAR. COMPACTA
15 to $18 \mathrm{in.}$
1.50
12.50
$1 \frac{1}{2}$ to $2 \mathrm{ft}$.
2.00
18.00

T. ELEGANTISSIMA

18 to 24 in.
2 to $2 \frac{1}{2} \mathrm{ft}$.
$2 \frac{1}{2}$ to $3 \mathrm{ft}$.

Gold Tipped Arbor Vitae 18.00

27.50

37.50

T. LUTEA

2 to $2 \frac{1}{2} \mathrm{ft}$.
$21 / 2$ to $3 \mathrm{ft}$.

2.50

Golden Arbor Vitae

22.50

32.50

T. OCCIDENTALIS GLOBOSA

Globe Arbor Vitae

12 to 15 in.

3.50

15 to 18 in.

2.00

2.50

18.00

150.00

22.50

T. OCC. GLOBOSA WOODWARDI
15 to 18 in.
2.00
18 to 24 in.
2.50

Woodward's Globe 
T. OCCIDENTALIS PLICATA

12 to $18 \mathrm{in}$.
18 to 24 in.
2 to $3 \mathrm{ft}$.
3 to $4 \mathrm{ft}$.

Each
1.25
2.00
3.00
4.50

Douglas Arbor Vitae Per 10 Per 100 11.00

18.00

27.50

40.00

160.00 240.00 375.00

T. OCCIDENTALIS VAR. PYRAMIDALIS

Pyramid Arbor Vitae

$\begin{array}{ll}18 \text { to } 24 \mathrm{in} . & 2.00 \\ 2 \text { to } 3 \mathrm{ft} . & 3.50 \\ 3 \text { to } 31 / 2 \mathrm{ft} . & 4.50 \\ 31 / 2 \text { to } 4 \mathrm{ft} & 5.00 \\ 41 / 2 \mathrm{ft} & 7.50 \\ 5 \mathrm{ft} . & 8.50\end{array}$

18.00

175.00

32.50

300.00

4.50

42.50

$5 \mathrm{ft}$.

8.50

T. OCCIDENTALIS VAR. VERVAENEANA

$\begin{array}{ccc}18 \text { to } 24 \text { in. } & 2.00 & 18.00 \\ 2 \text { to } 21 / 2 \mathrm{ft} . & 3.00 & 27.00 \\ 21 / 2 \text { to } 3 \mathrm{ft} . & 4.00 & 35.00\end{array}$

T. OCCIDENTALIS VAR. WAREANA Siberian Arbor Vitae

18 in.

$2 \mathrm{ft}$.

2 to $2 \frac{1}{2} \mathrm{ft}$.

2.00

3.00

3.50

TSUGA CANADENSIS

$11 / 2$ to $2 \mathrm{ft}$.
2 to $2 \frac{1}{2} \mathrm{ft}$.
$2^{1 / 2}$ to $3 \mathrm{ft}$.
3 to $31 / 2 \mathrm{ft}$
$31 / 2$ to $4 \mathrm{ft}$
4 to $5 \mathrm{ft}$
5 to $5 \frac{1 / 2}{\mathrm{ft} .}$

3.00

3.50

4.50

6.00

7.50

10.00

12.50
Hemlock

27.00

33.00

250.00
18.00

27.00 


\section{EVERGREEN SHRUBS}

ANDROMEDA FLORIBUNDA

Each

12 to 15 in.
Lily-of-the-Valley Shrub

Per 10 Per 100

20.00

BUXUS

Boxwood

For several years we have not included this valuable decorative shrub owing to the United States Quarantine forbidding inportations of such trees from Europe, the only place where they were obtainable at that time.

'This year we are again offering trees of Boxwoods, grown in this country, in pyramid shape in tubs.
2 feet
$2 \frac{1}{2}$ feet
$\$ 4.50$ each
$\$ 8.50$ per pair
5.50 each
10.00 per pair

DAPHNE CNEORUM

Garland Flower

$\begin{array}{rr}6 \text { to } 8 \text { in. } & .75 \\ 8 \text { to } 10 \text { in. } & 1.00 \\ 10 \text { to } 12 \text { in. } & 1.25 \\ 12 \text { to } 15 \text { in. } & 1.75\end{array}$

EUONYMUS RADICANS

Climbing Euonymus

$\begin{array}{ll}2 & \text { years } \\ 3 \text { years } & .50\end{array}$

4.50

4.80

36.00

E. RADICANS VAR. VARIEGATA

Variegated Climbing Euonymus
2 years
.50
4.50
3 years
.60
4.80
36.00

E. RADICANS VEGETUS

3 years

KALMIA LATIFOLIA

$$
\begin{aligned}
& 12 \text { to } 15 \mathrm{in} \text {. } \\
& 15 \text { to } 18 \mathrm{in} \text {. } \\
& 1 \frac{1}{2} \text { to } 2 \mathrm{ft} \text {. } \\
& 2 \text { to } 2 \frac{1}{2} \mathrm{ft} \text {. }
\end{aligned}
$$

Broad-leaved Climbing Euonymus
.75

1.25

2.00

3.00

4.00

\section{LAUREL See Kalmia}

LEUCOTHOE CATESBAEI

12 to 15 in.
15 to 18 in.
18 to 24 in.

PACHYSANDRA TERMINALIS

2 years

2 years pot grown

RHODODENDRON CAROLINIANUM

$$
\begin{aligned}
& 12 \text { to } 18 \mathrm{in} \text {. } \\
& 1 \frac{1}{2} \text { to } 2 \mathrm{ft} \text {. }
\end{aligned}
$$

2.00

4.00 6.00

Mountain Laurel

12.00

18.00

Drooping Andromeda

$$
14.00
$$

18.00

Japanese Spurge

$$
2.10
$$$$
2.50
$$

15.00

22.50

Carolina Rhododendron 
R. CATAWBIENSE

$$
\begin{aligned}
& 12 \text { to } 18 \mathrm{in} \text {. } \\
& 11 / 2 \text { to } 2 \mathrm{ft} \text {. } \\
& 2 \text { to } 2 \frac{1}{2} \mathrm{ft} \text {. }
\end{aligned}
$$

Native Red Rhododrendron

$\begin{array}{lll}\text { Each } & \text { Per } 10 & \text { Per } 100 \\ 2.50 & 22.00 & \\ 2.75 & 24.00 & \\ 4.00 & & \end{array}$

Rhododendron

R. HYBRIDS

These come in various colors.

$\begin{array}{ll}15 \text { to } 18 \mathrm{in} . & 3.00 \\ 11 / 2 \text { to } 2 \mathrm{ft} . & 3.75 \\ 2 \text { to } 21 / 2 \mathrm{ft} & 4.50\end{array}$

R. MAXIMUM

12 to 18 in.

$11 / 2$ to $2 \mathrm{ft}$.

2 to $21 / 2 \mathrm{ft}$.

$3 \mathrm{ft}$.

$3 \frac{1}{2} \mathrm{ft}$.

$4 \mathrm{ft}$.

YUCCA FILAMENTOSA

3 years
Native White Rhododendron
1.75
2.50
3.00
4.00
5.00
6.00

15.00

21.00

27.00

Adam's Needle

.40

24.00

\section{HEDGE PLANTS}

BARBERRY, THUNBERGS OR JAPANESE

\author{
12 to 18 in. \\ 18 to 24 in. Heavy \\ 24 to 30 in.
}

PRIVET, AMOOR RIVER

18 to 24 in.

24 to 36 in.

36 to 48 in.

PRIVET, CALIFORNIA
Per Doz. Per 100

2.40

3.60

4.50

15.00

25.00

36.00

2.40

3.00

4.20

12.00

15.00

22.50

.75

1.20

1.80

2.10
5.00

8.00

10.00

15.00

PRIVET, IBOLIUM

A cross between Ibota and California Privet. It has the attractive dark green leaves of the California but is of a more hranching habit, making a more compact hedge in less time. Reports that Ibolium show no signs of winter injury, when California has been killed to the ground, are being received from many places in the New England and Middle States.

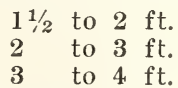

PRIVET, IBOTA
1.80

2.40

3.60 22.50
18 to 24 in.
24 to 36 in.
36 to 48 in. 


\section{DECIDUOUS SHRUBS}

ACANTHOPANAX PENTAPHYLLA

2 to $3 \mathrm{ft}$.

aLMOND See Prunus

ALTHEA See Hibiscus

ARALIA See Acanthopanax AZALEA ARBORESCENS

$$
\begin{aligned}
& 12 \text { to } 18 \mathrm{in} \text {. } \\
& 11 / 2 \text { to } 2 \mathrm{ft} \text {. }
\end{aligned}
$$

2.00

A. CANADENSIS

$$
12 \text { to } 18 \text { in. }
$$

$11 / 2$ to $2 \mathrm{ft}$.

1.00

1.50

A. LUTEA (Calandulacea)

$$
12 \text { to } 18 \mathrm{in.}
$$$$
1 \frac{1}{2} \text { to } 2 \mathrm{ft} \text {. }
$$

2.50

A. MOLLIS

$$
12 \text { to } 18 \text { in. }
$$

2.50

A. NUDIFLORA

$$
\begin{aligned}
& 12 \text { to } 18 \text { in. } \\
& 11 / 2 \text { to } 2 \mathrm{ft} \text {. }
\end{aligned}
$$

1.75

A. POUKHANESIS

$$
\begin{aligned}
& 15 \text { to } 18 \mathrm{in} \text {. } \\
& 18 \text { to } 24 \mathrm{in.}
\end{aligned}
$$

A. VISCOSA

$$
\begin{aligned}
& 12 \text { to } 18 \mathrm{in} \text {. } \\
& 11 / 2 \text { to } 2 \mathrm{ft} \text {. } \\
& 2 \text { to } 21 / 2 \mathrm{ft} \text {. }
\end{aligned}
$$

A. YODOGAWA

$$
12 \text { to } 15 \text { in. }
$$$$
3.00
$$

BENZOIN AESTIVALE (Lindera)

$$
1 \frac{1}{2} \text { to } 2 \mathrm{ft} \text {. }
$$$$
2 \text { to } 3 \mathrm{ft} \text {. }
$$

BERBERIS THUNBERGII

$$
\begin{aligned}
& 12 \text { to } 18 \mathrm{in} \text {. } \\
& 1 \frac{1}{2} \text { to } 2 \mathrm{ft} \text {. } \\
& 2 \text { to } 2 \frac{1}{2} \mathrm{ft} .
\end{aligned}
$$

B. THUNBERGII NANA

$$
12 \text { to } 15 \mathrm{in} \text {. }
$$

Aralia

Per 10 Per 100

$4.50 \quad 36.00$

\begin{tabular}{l}
$5.50 \quad \mathbf{4 5 . 0 0}$ \\
\hline
\end{tabular}

6.5()$\quad 60.00$
White Fragrant Azalea

Rhodora

$$
9.00
$$

Flame Azalea

$$
14.00
$$$$
22.50
$$

Japanese Azalea

Purple Azalea

Korean Azalia 30.00 42.00

Swamp Pink

12.50

17.50

22.50

Double Japanese Azalea

Spice Bush

Japanese Barberry

$$
2.00
$$

15.00

3.00

25.00

3.75

36.00

Box Barberry 3.60 30.00

B. THUNBERGII ATROPURPUREA Red-leaved Jap. Barberry Similar in habit to the well known Japanese Barberry. The foliage is bright red the entire season. 
BRIDAL WREATH See Spirea Prunifolia

BUDDLEIA DAVIDII MAGNIFICA (Variabilis) Butterfly Bush

2 vr. plants

CALYCANTHUS FLORIDA

2 to $3 \mathrm{ft}$.

CARAGANA ARBORESCENS

2 to $3 \mathrm{ft}$. $\quad .50$

3 to $4 \mathrm{ft}$. $\quad .60$

4 to $5 \mathrm{ft}$. Standards .75

5 to $6 \mathrm{ft}$. Standards 1.00

6 to $7 \mathrm{ft}$. Stanclards 1.50

CHIONANTHUS VIRGINICA

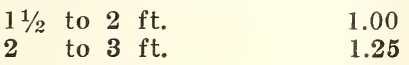

CLETHRA A.LNIFOLIA

$11 / 2$ to $2 \mathrm{ft}$.

2 to $3 \mathrm{ft}$.

CORNUS ALBA (Siberica)

2 to $3 \mathrm{ft}$.

3 to $4 \mathrm{ft}$.

C. ALBA ELEGANTISSIMA

2 to $3 \mathrm{ft}$.

3 to $4 \mathrm{ft}$.

C. MASCULA

3 to $4 \mathrm{ft}$.

4 to $5 \mathrm{ft}$.

Each

.50

.75

0

5

1.00

\section{.50}

.60

.50

.60

.75

.90

.60

.75

C. STOLONIFERA LUTEA (Aurea)

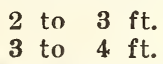

Per 10 Per 100

$4.00 \quad 30.00$

Allspice

6.00

Siberian Pea

White Fringe

Sweet Pepper Bush

$\begin{array}{ll}4.20 & 30.00\end{array}$

$4.50 \quad 36.00$

Red-bark Dogwood

3.60

27.00

4.50

36.00

Variegated Cornus

6.00

50.00

7.00

65.00

Cornelian Cherry

4.50

6.00

Golden-bark Dogwood

4.20

4.50

COTTONEASTER HORRIZONTALIS

A beautiful plant for terraces, slopes, tops of low walls, foundation planting, etc. Fan shaped, prostrate branches, and red berries in Fall.

Field grown stock does not transplant safely, so we only offer excellent stock from pots.

CYDONIA JAPONICA

$1 \frac{1}{2}$ to $2 \mathrm{ft}$.

DAPHNE MEZERIUM

18 to 24 in.

1.00

DESMODIUM PENDULIFLORUM

2 years

DEUTZIA CRENATA

$$
2 \text { to } 3 \mathrm{ft} \text {. }
$$

3 to $4 \mathrm{ft}$.

D. GRACILIS

10 to 12 in.

12 to $18 \mathrm{in}$.

$11 / 2$ to $2 \mathrm{ft}$.
.60

1.00

.60

.75
8.00

Japanese Quince 4.50

6.00

9.00

Sweet Pea Shrub

4.00

6.00

30.00

Dwarf Deutzia

3.50

4.50

6.00

30.00 
D. LEMOINEI

$\begin{array}{lccr}12 & \text { Fach } & \text { Per } 10 & \text { Per } 100 \\ 18 \text { to } 24 \text { in. } & .45 & 4.00 & 36.00 \\ 24 \text { to } 30 \text { in. } & .60 & 5.00 & \end{array}$

D. PRIDE OF ROCHESTER

$\begin{array}{llll}11 / 2 \text { to } 2 \mathrm{ft} . & .40 & 3.00 & 25.00 \\ 2 \text { to } 3 \mathrm{ft} . & .50 & 4.00 & 30.00 \\ 3 \text { to } 4 \mathrm{ft} . & .75 & 6.00 & \end{array}$

D. SCABRA

$$
\begin{aligned}
& 2 \text { to } 3 \mathrm{ft} \text {. } \\
& 3 \text { to } 4 \mathrm{ft} \text {. }
\end{aligned}
$$

EUONYMUS ALATUS

$$
\begin{array}{r}
18 \text { to } 24 \mathrm{in} \text {. } \\
2 \text { to } 3 \mathrm{ft} \text {. } \\
3 \text { to } 4 \mathrm{ft} \text {. }
\end{array}
$$

$\begin{array}{ccr}.50 & 4.00 & \\ .75 & 6.50 & \\ \text { Winged-bark } & \text { Strawberry } & \text { Shrub } \\ .75 & 6.00 & 54.00 \\ 1.00 & 9.00 & \\ 1.75 & 16.50 & \end{array}$

\section{E. ALATUS COMPACTA}

A very bushy compact form of shrub more dwart in habit than Alatus. Grows well in shady places. Foliaze in fall intense scarlet.
12 to 18 in.
.75
18 to 24 in.
1.25
2 to $2 \frac{1}{2} \mathrm{ft}$.
2.00
6.50
12.00
18.00
60.00
110.00

EXOCHORDA GRANDIFLORA

Pearl Bush

2 to 3 ft.

.75

FORSYTHIA FORTUNEII

2 to $3 \mathrm{ft}$.

$3 \mathrm{th} 4 \mathrm{ft}$.

F. INTERMEDIA

2 to $3 \mathrm{ft}$.

3 to $4 \mathrm{ft}$.

.60

F. SUSPENSA

3 to $4 \mathrm{ft}$.

.75

GOLDEN BELL See Forsythia HONEYSUCKLE See Lonicera HAMAMELIS VIRGINICA

2 to $3 \mathrm{ft}$.

HIBISCUS SYRIACUS (ALTHEA)

2 to $3 \mathrm{ft}$.
3 to $4 \mathrm{ft}$.
Standards

Fortune's Golden Bell
4.20
30.00

4.80

36.00

Golden Bell

$4.20 \quad 30.00$

$4.50 \quad 36.00$

Weeping Golden Bell 6.50

HYDRANGEA ARBORESCENS GRANDIFLORA

Witch Hazel

Rose of Sharon 4.50

6.50

Snowball Hydrangea

$\begin{array}{llll}11 / 2 & \text { to } & 2 \mathrm{ft} . \\ 2 & \text { to } & 3 & \mathrm{ft} . \\ 3 & \text { to } & 4 \mathrm{ft} .\end{array}$

7.00

H. PANICULATA

Single Flower 
H. PANICULATA GRANDIFLORA

Tree Form.

$\begin{array}{rrrr}2 & \text { to } 3 \mathrm{ft} . & .75 & 6.50 \\ \mathbf{3} & \text { to } 4 \mathrm{ft} . & 1.25 & 10.00 \\ 4 & \text { to } 5 \mathrm{ft} & 1.50 & 12.00\end{array}$

HYPERICUM DENSIFLORUM $11 / 2$ to $2 \mathrm{ft}$.

ILEX VERTICILLATA $11 / 2$ to $2 \mathrm{ft}$. Each .50 .65 .75

$11 / 2$ to $2 \mathrm{ft}$. 2 to $3 \mathrm{ft}$. 1.50 .50 .50 JAPANESE QUINCE See Cydonia KERRIA JAPONICA FLORA PLENO 2 to $3 \mathrm{ft}$. .75

K. JAPONICA VARIEGATA 12 to 15 in. .60

L.IGUSTRUM AMURENSE

$$
\begin{array}{lll}
11 / 2 & \text { to } 2 & \mathrm{ft} . \\
2 & \text { to } 3 \mathrm{ft} \\
3 & \text { to } & 4 \mathrm{ft} .
\end{array}
$$

L. IBOLIUM

$$
\begin{array}{llll}
1 \frac{1}{2} & \text { to } 2 & \mathrm{ft} \\
2 & \text { to } 3 \mathrm{ft} &
\end{array}
$$

L. IBOTA

$$
\begin{array}{lll}
\mathrm{l}^{1 / 2} & \text { to } 2 \mathrm{ft} . \\
2 & \text { to } 3 & \mathrm{ft} . \\
3 & \text { to } & 4 \mathrm{ft} .
\end{array}
$$

L. IBOTA VAR. REGELIANUM

$$
\begin{aligned}
& 12 \text { to } 18 \mathrm{in} \text {. } \\
& 11 / 2 \text { to } 2 \mathrm{ft} \text {. } \\
& 2 \text { to } 21 / 2 \mathrm{ft} \text {. }
\end{aligned}
$$

L. OVALIFOLIUM

$$
\begin{aligned}
& 12 \text { to } 18 \mathrm{in} . \\
& 11 / 2 \text { to } 2 \mathrm{ft} . \\
& 2 \text { to } 3 \mathrm{ft} . \\
& 3 \text { to } 4 \mathrm{ft} .
\end{aligned}
$$

LILAC See Syringa

LONICERA FRAGRANTISSIMA

$$
2 \text { to } 3 \mathrm{ft} \text {. }
$$$$
3 \text { to } 4 \mathrm{ft} \text {. }
$$

L. MORROWII

$$
\begin{aligned}
& 2 \text { to } 3 \mathrm{ft} \text {. } \\
& 3 \text { to } 4 \mathrm{ft} \text {. }
\end{aligned}
$$

$.3 n$

.40

Common Hydrangea Per 10 Per 100 4.50 5.40 6.50

36.00 45.00 60.00

St. John's Wort Black Alder Globe Flower 6.00

\subsection{0}

Amoor Privet

$\begin{array}{ll}2.00 & 12.00 \\ 2.50 & 15.00 \\ 3.50 & 22.50\end{array}$

Ibolium Privet

$\begin{array}{ll}1.50 & 12.00 \\ 2.00 & 1 \% .50 \\ 3.00 & 22.50\end{array}$

Japanese Privet 1.75

2.50

3.50

$\begin{array}{lr}\text { Regell's } & \text { Privet } \\ 3.00 & 25.00 \\ 3.50 & 30.00\end{array}$

California Privet

$\begin{array}{rr}.60 & 5.00 \\ 1.00 & 8.00 \\ 1.50 & 10.00 \\ 1.75 & 15.00\end{array}$

Fragrant Bush Honeysuckle .60 .75

.50 .75

$$
4.00
$$

30.00

L. RUPRECHTIANA

2 to $3 \mathrm{ft}$. 
L. TARTARICA VAR. ALBA White Tartarian Honeysuckle 3 to $4 \mathrm{ft} \quad$ Each $\quad$ Per 10 Per 100

L. TARTARICA GRANDIFLORA

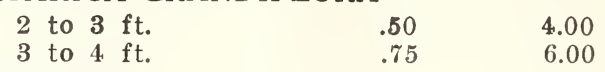

L. XYLOSTEUM

2 to $3 \mathrm{ft}$.

3 to $4 \mathrm{ft}$.

MYRICA CERIFERA

15 to 18 in.

$11 / 2$ to $2 \mathrm{ft}$.

2 to $3 \mathrm{ft}$.

.50

.75

.50

.60

1.00

PHILADELPHUS CORONARIUS

2 to $3 \mathrm{ft}$.

3 to $4 \mathrm{ft}$.

.50

.60

P. CORONARIUS VAR. AUREA

12 to 18 in.

$11 / 2$ to $2 \mathrm{ft}$.

P. ERECTA

2 to $3 \mathrm{ft}$.

3 to $4 \mathrm{ft}$.

P. GRANDIFLORA

2 to $3 \mathrm{ft}$.

3 to $4 \mathrm{ft}$.

P. VIRGINALIS

2 to $2 \frac{1}{2} \mathrm{ft}$.

.60

.75

.50

.75

.50

.60

Double Flowering Syringa 1.00

PRUNUS JAPONICA, ALBA \& RUBRA

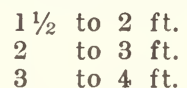

PURPLE FRINGE See Rhus Cotinus

1.00

Fly Honeysuckle 4.00

6.00

Bayberry

5.50 50.00

9.00

Mock Orange

$4.00 \quad 30.00$

$4.50 \quad 36.00$

Golden-Leaf Syringa

5.00

6.00

45.00

4.00

6.00

Large Flowered Syringa 4.00 4.50

30.00

36.00

Flowering Almond 5.00

6.50

9.00

PYRUS JAPONICA See Cydonia

RHODOTYPOS KERRIOIDES

$$
\begin{array}{r}
18 \text { to } 24 \mathrm{in} \text {. } \\
2 \text { to } 3 \mathrm{ft} \text {. } \\
3 \text { to } 4 \mathrm{ft} \text {. }
\end{array}
$$

RHUS COTINUS

$$
2 \text { to } 3 \mathrm{ft} \text {. }
$$

R. CANADENSIS (Aromatica)

$$
11 / 2 \text { to } 2 \mathrm{ft} \text {. }
$$$$
2 \text { to } 3 \mathrm{ft} \text {. }
$$

R. COPALLINA

$$
2 \text { to } 3 \mathrm{ft} \text {. }
$$$$
3 \text { to } 4 \mathrm{ft} \text {. }
$$

R. TYPHINA LACINIATA

RUBUS ODORATUS

$$
1 \frac{1}{2} \text { to } 2 \mathrm{ft} \text {. }
$$$$
2 \text { to } 3 \mathrm{ft} \text {. }
$$

2 to $3 \mathrm{ft}$.
White Kerria 4.00 5.00

Purple Fringe

Fragrant Sumac 4.50 B. 00

Shining Sumac

Cut-leaf Sumac 3.00 4. 00

Flowering Raspberry 4.20 
ROSA RUGOSA

R. RUGOSA ALBA

$1 \frac{1}{2}$ to $2 \mathrm{ft}$.

R. RUGOSA RUBRA

$$
\begin{aligned}
& 12 \text { to } 181 \mathrm{r} \text {. } \\
& 11 / 2 \text { to } 2 \mathrm{ft} \text {. } \\
& 2 \text { to } 3 \mathrm{ft} \text {. }
\end{aligned}
$$

SAMBUCUS AUREA

$$
\begin{aligned}
& 2 \text { to } 3 \mathrm{ft} \text {. } \\
& 3 \text { to } 4 \mathrm{ft} \text {. }
\end{aligned}
$$

S. CANADENSIS

$$
2 \text { to } 3 \mathrm{ft} \text {. }
$$

SPIREA ARGUTA

$$
\begin{aligned}
& 2 \text { to } 3 \mathrm{ft} \text {. } \\
& 3 \text { to } 4 \mathrm{ft} \text {. }
\end{aligned}
$$

S. BUMALDI

$$
\begin{aligned}
& 12 \text { to } 18 \text { in. } \\
& 1 \frac{1 / 2}{2} \text { to } 2 \mathrm{ft} \text {. }
\end{aligned}
$$

S. BUMALDA VAR. FROEBELI $1 \frac{1}{2}$ to $2 \mathrm{ft}$. 2 to $3 \mathrm{ft}$.

S. BUMALDA VAR. WATERII

$$
12 \text { to } 15 \text { in. }
$$$$
1 \frac{1}{2} \text { to } 2 \mathrm{ft} \text {. }
$$

S. CALLOSA ALBA

$$
\begin{array}{ll}
1 & \mathrm{ft} . \\
1 / 2 \mathrm{ft}
\end{array}
$$

S. OPULIFOLIA

$$
\begin{aligned}
& 2 \text { to } 3 \mathrm{ft} \text {. } \\
& 3 \text { to } 4 \mathrm{ft} \text {. }
\end{aligned}
$$

S. OPULIFOLIA AUREA

$$
\begin{aligned}
& 2 \text { to } 3 \mathrm{ft} \text {. } \\
& 3 \text { to } 4 \mathrm{ft} \text {. }
\end{aligned}
$$

\section{S. PRUNIFOLIA FLORA PLENA}

$$
2 \text { to } 3 \mathrm{ft} \text {. }
$$

Japanese Rose

White Rugosa

Per 10 Per 100

5.00

4.5 .00

Pink Rugosa

$\begin{array}{ll}3.00 & 22.50 \\ 4.20 & 30.00 \\ 4.80 & 39.00\end{array}$

Golden Elder

4.20

4.80

Common Elderberry 4.00

$$
\begin{array}{ll}
4.50 & 39.00 \\
6.00 & 54.00
\end{array}
$$

Dwarf Pink Spirea 3.60 4.50

30.00 40.00

$\begin{array}{rr}\text { Crimson Spirea } \\ 3.60 & 30.00 \\ 4.50 & 36.00\end{array}$

Dwarf Crimson Spirea 3.00

3.60

4.50)

30.00

Dwarf White Spirea

4.00

4.50

Ninebark

4.00

6.00

Golden-Leaved Spirea 4.00

6.00

Bridal Wreath

$$
4.50
$$

6.00

4.00

4.80

\section{S. TRICHOCARPA}

$\begin{array}{llll}11 / 2 & \text { to } 2 \mathrm{ft} . & .50 & 4.00 \\ 2 & \text { to } 3 \mathrm{ft} . & .60 & 4.80\end{array}$

Similar to Van Houtii. Flowers two or three weeks later. 3 to $4 \mathrm{ft}$.
1.00
9.00

S. VAN HOUTTEI

$\begin{array}{lll}2 & \text { to } & 3 \mathrm{ft} . \\ 3 & \text { to } & 4 \\ \mathrm{ft}\end{array}$

4 to $5 \mathrm{ft}$.

STEPHANANDRA FLEXUOSA 
SYMPHORECARPUS CHENAULTI

A new improved coral berry.
2 to $3 \mathrm{ft}$.
Each
Per 10 Per 100
.75
6.00

S. RACEMOSUS

2 to $3 \mathrm{ft}$.

3 to $4 \mathrm{ft}$.

S. VULGARIS

$$
\begin{array}{llll}
11 / 2 & \text { to } 2 & \mathrm{ft} . \\
2 & \text { to } 3 \mathrm{ft} .
\end{array}
$$

S. VULGARIS VARIEGATA

$$
1 \frac{1}{2} \text { to } 2 \mathrm{ft} \text {. }
$$

2 to $3 \mathrm{ft}$.
.50

.75

.40

.50

Variegated Indian Currant

$\begin{array}{lll}.40 & 3.00 & 25.00 \\ .50 & 4.00 & 30.00\end{array}$

Lilac

\section{SYRINGA}

These we offer in many varieties, including a great variation in colors both single and double.

S. JAPONICA

$$
2 \mathrm{to} 3 \mathrm{ft} \text {. }
$$

S. ROTHOMAGENSIS

2 t' $3 \mathrm{ft}$. lushes

3 to 4 ft. trees

S. VILLOSA

$$
2^{1 / \%} \text { to } 2 \mathrm{ft} .
$$

S. VULGARIS

$$
\begin{array}{llll}
11 / 2 & \text { to } & 2 & \mathrm{ft} . \\
2 & \text { to } & 3 \mathrm{ft} . \\
3 & \text { to } & 4 \mathrm{ft} .
\end{array}
$$

S. VULGARIS ALBA

$$
\begin{array}{llll}
11 / 2 & \text { to } & 2 & \mathrm{ft} \\
2 & \text { to } & 3 & \mathrm{ft}
\end{array}
$$

S. VULGARIS HYBRIDS
Japanese Lilac

Rouen Lilac

4.50

5.40

Common Purple Lilac 3.00

$5.50 \quad 50.00$

$7.00 \quad 65.00$

Common White Lilac 3.00

6.50

9.00

85.00

Grafted or Names Sorts

\section{VARIETIES, SINGLE FLOWERED:}
Ainbrose Vershaffelt
-Pale Lilac
Amelia Dupret
Amoena
Amethyst
- Light Blue
Charles X
-Reddish Lilac
-Blueish Lilac
Congo
Furst Lichtenstein
--Reddish-Purple
Glori Lorraine
Justi
Mme. Lemoine
Michael Buchner
Mne. Casimir Perier
Prince Imperial
-Dark Crimson
-Blue
-Crimson Pink Buds
-Blueish Early
-White
- Clear Lilac Purple
-White
-Reddish

\section{VARIETIES, DOUBLE FLOWERED:}
Alphonse Laville
Belle de Nancy
Dr. Master's

-Light Blue

- Satin Pink

-Blueish Lilac 
Doyenne Keteler

Grand duc Constantine

Languis

Marlyensis Pallida

Marie LeGrey

Obelesque

Renoncoule

Rubra de Marley

Souv. de Ludwig Spaeth

Valentina

Ville de Troyes

Virginalis
-Light Pink

- Blueish Lilac

-Blueish

- Reddish Purple

-White

- White

- I.ight Lilac

- Purple

- Red

- Lilac

-Dark Purple

-White

Many other varieties in limited quantity. Ask for list.

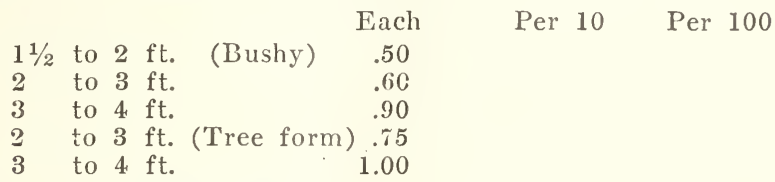

SYRINGA See Philadelphus

VIBURNAM AMERICANA

$$
\begin{array}{r}
18 \text { to } 24 \text { in. } \\
2 \text { to } 3 \mathrm{ft} .
\end{array}
$$

VIBURNUM CARLESII

$$
\begin{array}{ll}
1 & \mathrm{ft} . \\
1^{1 / 2} & \mathrm{ft} .
\end{array}
$$

\section{VIBURNUM DENTATUM}

$$
\begin{array}{r}
18 \text { to } 24 \mathrm{in} . \\
2 \text { to } 3 \mathrm{ft} . \\
3 \text { to } 4 \mathrm{ft} .
\end{array}
$$

V. JAPONICA (Sieboldi)

$$
\begin{aligned}
& 1 \frac{1}{2} \text { to } 2 \mathrm{ft} \text {. } \\
& 2 \text { to } 3 \mathrm{ft} \text {. }
\end{aligned}
$$

V. LANTANA

$$
\begin{aligned}
& 2 \text { to } 3 \mathrm{ft} \text {. } \\
& 3 \text { to } 4 \mathrm{ft} \text {. }
\end{aligned}
$$

V. LENTAGO

$$
\begin{array}{lll}
1 \frac{1}{2} & \text { to } 2 \mathrm{ft} . \\
2 & \text { to } 3 \mathrm{ft} . \\
3 & \text { to } 4 \mathrm{ft} .
\end{array}
$$

V. MOLLE

$$
\begin{aligned}
& 18 \text { to } 24 \text { in. } \\
& 2 \text { to } 3 \mathrm{ft} \text {. }
\end{aligned}
$$

V. OPULUS

$$
\begin{array}{lll}
11 / 2 & \text { to } 2 \mathrm{ft} .
\end{array}
$$

V. OPULUS NANA

$$
\begin{array}{r}
6 \text { to } 8 \mathrm{in} . \\
8 \text { to } 10 \mathrm{in.} \\
10 \text { to } 12 \mathrm{in.}
\end{array}
$$

Am. Cranberry Tree 4.00 5.00

Mayflowered Viburnum

Arrow Wood

36.00

\subsection{0}

6.00

Wayfaring Tree

\subsection{0}

6.00

$\begin{array}{lr} & \text { Sheep Berry } \\ 4.00 & \\ 5.40 & 45.00\end{array}$

Kentucky Viburnam 4.00

5.00

\section{Cranberry Tree}

4.00

5.00

Dwarf Viburnum

3.00

3.50 
V. OPULUS STERILE

$\begin{array}{rc}18 \text { to } 24 \text { in. } & \text { Each } \\ 2 \text { to } 3 \mathrm{ft} . & .50 \\ & .60\end{array}$

V. TOMENTOSUM

$$
1 \frac{1}{2} \text { to } 2 \mathrm{ft} \text {. }
$$$$
3 \text { to } 4 \mathrm{ft} \text {. }
$$

V. TOMENTOSUM PLICA IUM 18 to 24 in.

WEIGELIA CANDIDA

$$
\begin{aligned}
& 2 \text { to } 3 \mathrm{ft} \text {. } \\
& 3 \text { to } 4 \mathrm{ft} \text {. }
\end{aligned}
$$

W. EVA RATHKE

$$
\begin{aligned}
& 12 \text { to } 18 \text { in. } \\
& 18 \text { to } 24 \text { in. }
\end{aligned}
$$

W. ROSEA

$$
\begin{aligned}
& 2 \text { to } 3 \mathrm{ft} \text {. } \\
& 3 \text { to } 4 \mathrm{ft} \text {. }
\end{aligned}
$$

.50

.75

.75

.60

.75

.50

.75

.50

.60

W. ROSEA VARIEGATA

$$
\begin{array}{llll}
11 / 2 & \text { to } 2 & \mathrm{ft} \\
2 & \text { to } & 3 \mathrm{ft} \\
3 & \text { to } & 4 \mathrm{ft}
\end{array}
$$

XANTIIORRHIZA APIIFOLIA

Dwarf shrub much used for undergrowth.

$$
10 \text { to } 12 \mathrm{in.}
$$

Common Snowball Per 10 Per 100 4.00

Single Japan Snowball 4.50 6.50

Japanese Snowball

5.00 45.00

$\begin{array}{lr} & \text { Red Weigelia } \\ 4.50 & 36.00 \\ 6.00 & 54.00\end{array}$

Pink Weigelia

$\begin{array}{ll}4.20 & 39.00 \\ 5.00 & \end{array}$

Variegated Weigelia

4.80

5.50

4.5 .00

6.50

50.00

Yellow Root

3.00

21.00

\section{CLIMBING VINES}

ACTINIDIA ARGUTA

$$
2 \text { years }
$$

AKEBIA QUINATA

$$
2 \text { years }
$$

AMPELOPSIS QUINQUEFOLIA

$$
2 \text { years }
$$$$
3 \text { years }
$$

A. QUINQUEFOLIA ENGLEMANII 2 years

3 years

A. VEITCHII

$$
2 \text { years }
$$

ARISTOLOCHIA SIPHO

$$
\begin{aligned}
& 2 \text { years } \\
& 3 \text { years } \\
& 4 \text { years extra }
\end{aligned}
$$

Silver Sweet Vine Per 10 Per 100 6.00

$\begin{array}{cr} & \text { Woodbine } \\ 4.00 & 25.00 \\ 4.50 & \mathbf{3 0 . 0 0} \\ \text { Engleman's Ivy } \\ 4.00 & 25.00 \\ 4.50 & 30.00 \\ & \text { Boston Ivy } \\ 6.00 & 55.00 \\ 7.50 & 65.00 \\ \text { Dutchman's Pipe } \\ 9.00 & 75.00 \\ 10.00 & 90.00 \\ 18.00 & 150.00\end{array}$


A. TOMENTOSUM

\begin{tabular}{lccc} 
& Each & Per 10 & Per 100 \\
2 years & .50 & 4.50 & \\
3 years & .75 & 6.00 \\
NIA RADICANS & \multicolumn{2}{c}{ Trumpet Vine } \\
3 years & .50 & 4.50
\end{tabular}

BITTER SWEET See Celastris Scandens

BOSTON IVY See Ampelopsis Veitchii

CELASTRIS SCANDENS

CLEMATIS
2 years
.50
$4.00 \begin{array}{r}\text { Bitter Sweet } \\ 30.00\end{array}$

Jackmanii-Purple or Blue Henryi-White Mad. Edward Andre-Red
2 years
1.00
7.50

c. PANICULATA

2 years medium

2 years extra

.50

.60

3 years

.75

Japanese Virgin Bower

$\begin{array}{lr}4.00 & 30.00 \\ 4.50 & 40.00\end{array}$

HONEYSUCKLE See Lonicera

HUMULUS LUPULUS

3 years

LONICERA HALLEANA

2 years

3 years

L. SEMPERVIRENS

2 years

LYCIUM BARBATUM

3 years
.50

.50

.60

Scarlet Trumpet Honeysuckle .60

.60
Hop Vine

Japanese Honeysuckle

$$
4.00
$$

4.50

25.00
4.80

Matrimony Vine

MATRIMONY VINE See Lycium

WISTARIA SINENSIS

\begin{tabular}{|c|c|c|}
\hline & & \\
\hline years & Layers & .75 \\
\hline ars & Layers & 1.00 \\
\hline rs & Extra heavy & 1.50 \\
\hline
\end{tabular}

W. CHINENSIS ALBA

3 years

.75

Purple Wistaria.

$\begin{array}{ll}6.50 & 60.00 \\ 8.50 & 75.00\end{array}$

White Wistaria 6.50

60.00 


\section{Roses and Their Culture}

Our Roses are as hardy as trees, grown outdoors, and sure to give satisfaction, assuming customer knows how to handle them. If a Rose Bush dies after planting it is usually due to lack of trimming and lack of water. If the roots are kept wet for two weelss after planting they are sure to grow. Nearly all losses on Roses are due to lack of enough moisture, as the roots are as hardy as any tree we ship out. Customers should always remember that we have no control over our products after they leave our hands. We make them grow and the customer can do the same if he handles them properly.

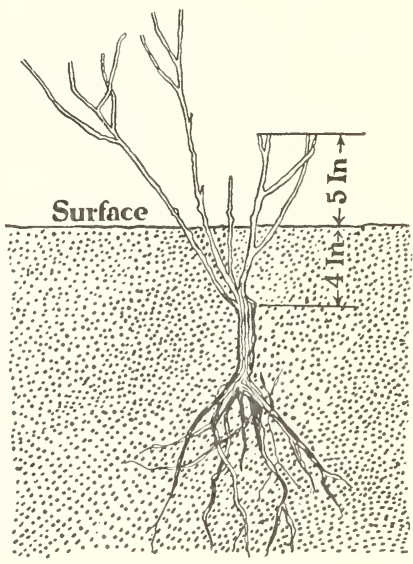

\section{HOW TO GROW ROSES}

Select a sunny location in the open, southern exposure preferred. sheltered, if possible, from north winds.

Prepare beds by using good soil and cow or well rotted horse manure. Old sod well cut is also beneficial. Beds should be at least two feet in deptlı. For convenience of customers we offer cow manure put up in bags. See inside last page of this catalogue.

\section{PLANTING}

Plant deep so that the branches, where they leave the trunk, will be four inches below the surface. 'Trim as shown in cut so as to leave not over 5 or 6 inches of wood above ground. Pound the soil firmly about the root and water thoroughly. If the soil and weather be dry, a good soaking of water may be applied, and then shade the ground and plants with mulching. If shaded by paper or other devices from drying winds until they commence growing, their success will be assured. The season for transplanting hardy Roses is April, May, October and November.

Pruning. This should be regulated by the habit of growth, the weak shoots cut in closely, the strong left longer. Moss Roses and Austrian Yellow Roses need the least pruning. Hybrid Perpetuals, grown to produce flowers for exhibition, require close pruning before the middle of April, the weak shoots being cut close back, and the strong ones to 5 or 6 eyes. If less is cut away, the number of blooms will be larger, but the size of the flowers will be smaller. Climbing Roses should have their 
old shoots and such as are weak entirely cut away, while several vigorous branches may be left their entire length.

Watering. In dry weather water is of much benefit, if properly applied. Frequent surface waterings are worse than none, for they seldom fail to produce bad health and disease. When water is given, it should be in sufficient quantity to reach the lower roots, and to prevent its quickly drying out a mulch on the surface is very useful.

For winter protection, draw the soil one foot high about the plants, or even more, if convenient. Manure can be put on for additional protection. It need not be rotted; green will answer just as well, and can be covered under in the spring.

\section{INSECTS}

A weekly application of Bordeaux-Arsenate of Lead Mixture, at the rate of eight ounces to five gallons of water, applied with sprayer, under side of foliage, during growing season will keep roses free from almost all insect pests and fungous diseases. A mulching of two inches of tobacco stems covering ground is very beneficial.

A liberal use of cold water, sprayed with force from the hose nozzle on the underside of the leaves, will keep the plants free from green fly and other insects.

Hellebore, Powdered White. For the destruction of slugs, worms, caterpillars, etc. Less poisonous than Paris Green and London Purple, and safer to use. Use as a powder or dissolve one ounce in three gallons of water.

\section{POT GROWN}

While we use every modern method possible to keep our dormant roses fresh for planting out, yet as the season advances the plants are certain to start or become dried to some extent. We, therefore, have established in pots plants of the same size as the dormant ones, and of the leading sorts, which may be planted as late as July and blossom the first season. By planting Pot Grown roses you will be assured that all will grow.

$\$ 1.00$ each; $\$ 10.50$ per doz.; $\$ 80.00$ per 100 .

A CHARGE WILL BE MADE FOR EARTHEN POTS.

\section{HYBRID TEA ROSES}

Two-year dormant plants, 90 c. each; $\$ 9.00$ per doz.; $\$ 65.00$ per 100 , except where noted.

Chateau de Clos Vougeot. Crimson center, fiery scarlet tips. Darkest H. T.

Columbia. Glowing pink. A splendid, large, fully double rose. Most attractive. 
Duchess of Wellington. A delightfully fragrant rose. Intense saff ron-yellow.

Edward Mawley. Rich velvety-crinson, globular flowers borne in profusion.

Etoile de France. Deep crimson with cerise-red center.

General McArthur. Brilliant crimson-scarlet A splendid rose.

Gruss an Teplitz. Rich scarlet slıading to crimson. Vigorous; free bloomer.

Jonkheer J. L. Mock. Outside of petals carmine, inside flesh pink.

Kaiserine Augusta Victoria. Cream, slightly shaded lemon. V'ery fragrant.

Killarney. Flesh, shaded white, suffused pale pink. A lovely variety.

Killarney Brilliant. Brilliant pink, alınost crimson. Very fragrant.

Killarney Queen. Deeper in color than the above; flowers more double.

Konigin Carola. Color a beautiful satiny rose; reverse of petals silvery rose.

Lady Alice Stanley. Beautiful coral-rose. A magnificent variety, nearly reaching perfection.

Lady Ashtown. Pale rose, shading to yellow at base of petals. Fine buds.

Lady Hillingdon. Deep apricot yellow; violet foliage; vigorous.

Lady Ursula. Flesh pink; large; tea scented; very free bloomer.

Laurent Carle. Brilliant velvety-carmine. A robust and free blooming rose.

Los Angeles. Coral pink.

Mme. Butterfly. Similar to Ophelia but larger flower; color bright pink, gold and apricot which are blended.

Mme. Edouard Herriot. Coral or brick-red. Greatly admired.

Mme. Caroline Testout. Beautiful silvery-rose. Excellent in every way.

Mme. Jules Grolez. Soft pink.

Mme. Ravary. Attractive golden yellow; sweet scented; free bloomer.

Mrs. Aaron Ward. Color Indian yellow, shading to lemon-cream at the edges of petals. Very large and full. A splendid new garden rose.

Mrs. Charles Russell. Deep rose to rosy pink. Has many excellent qualities.

Ophelia. Salmon-flesh, shading to rose. Grand.

Pharisaer. Silvery pink, suffused salmon. Fine buds; long stems.

Reine Marguerite d'Italie. Deep crimson, almost maroon. A great bloomer, especially in the fall. Very fragrant.

Radiance. Soft carmine-pink. Double; sweet-scented; free.

Red Radiance. A crimson sport of radiance. 
Souvenir de Claudius Pernet. The best and one of the few really' yellow, with a pointed bud and glossy foliage. $\$ 1.25$ each.

White Killarney. Pure white; productive; constant.

\section{HYBRID PERPETUAL ROSES}

Two-year dormant plants, 75 cents each; $\$ 7.50$ doz.; $\$ 60.00$ per 100, except where noted.

Alfred Colomb. Extra large, very double; color rich crimson; fragrant.

American Beauty. Very double, of a deep crimson color.

Anna de Diesbach. Brilliant carmine; delightfully fragrant. One of the best.

Baron de Bonstettin. Blackish crimson with maroon shadings.

Baroness Rothschild. Beautiful light pink, shaded white. Most desirable.

Captain Hayward. Bright crimson-carmine; of splendid form.

Clio. Flesh color, shading to rose in center. Large, fine, vigorous.

Fisher Holmes. Finely shaped flowers of dark velvety crimson.

Frau Karl Druschki. Pure paper white; large and free flowering. General Jacqueminot. Brilliant crimson color; large and fragrant. George Arends. The Pink Druschki. Soft pink; and free blooming. Distinct.

Mme. Gabriel Luizet. Beautiful satiny pink. A vigorous and healthy grower.

Magna Charta. A bright, clear pink, finished with crimson.

Margaret Dickson. White with pale flesh center. Good form; handsome foliage.

Marshall P. Wilder. Cherry red, mingled with carmine.

Mrs. John Laing. A constant blooming hardy rose. Color brilliant shell pink.

Mrs. R. G. S. Crawford. Deep rose pink; fine form, constant bloomer.

Paul Neyron. A deep rose color; produces largest flowers of any known rose.

Prince Camille de Rohan. Deep velvety crimson; flowers large. Best dark red.

Soleil d'Or. Golden yellow, shaded nasturtium red. Free blooming; hardv.

Ulrich Brunner. Blossoms are a bright cherry red, and very fragrant.

\section{CLIMBING ROSES}

Two-year dormant plants, 60 cents each; $\$ 6.00$ per doz.; $\$ 45.00$ per 100; except where noted.

American Pillar. Chaste pink; single blossoms.

Aviateur Bleriot. Rich, deep saffron-yellow. Fragrant. 75 cents. Christine Wright. Bright wild-rose pink. Flowers $3 \frac{1 / 2}{-4}$ in. in diameter. 
Climbing American Beauty. Rose pink; fragrant; good foliage.

Crimson Rambler. Large clusters of crimson flowers.

Dr. Van Fleet. Flesh pink. Flowers are full, double and fragrant. Choice.

Dorothy Perkins. Soft shell-pink.

Emily Gray. Long tapering golden yellow buds. $\$ 1.00$ each.

Excelsa. Intense crimson-maroon. Healthy foliage. Very fine. Hiawatha. Single. Crinson.

Mary Wallace. The new Van Fleet climber. Semi-double clear rose-pink with salinon base to petals.

Paul's Scarlet Climber. Vivid scarlet, semi-double flowers of mediunil size, whicl do not burn of facle in the sun. Produced in large clusters in great profusion. Extremely hardy. One of the nost promising clinbing roses of recent years. 2-year plants, $75 \mathrm{c}$.

Silver Moon. Clear silvery-white. Foliage is mildew-proof. Fragrant.

Tausendschon. Soft pink turning to flesh. The blossoms are produced in large trusses.

White Dorothy Perkins. Same as Dorothy Perkins, except color is white.

\section{BABY RAMBLER ROSES}

Two-year dormant plants, 75 cents each; $\$ 7.50$ per doz.; $\$ 60.00$ per 100 .

Baby Crimson R-mbler. Rosy crimson.

Baby Dorothy. Pink.

Baby Ideal. Most vivid scarlet.

Catherine Zeimet. Pure white flowers in abundance. Fragrant. Jessie. Bright scarlet.

Orleans. Red to rose.

\section{RUGOSA ROSES}

$\begin{array}{lrrr} & \text { Each } & \text { Per 10 } & \text { Per } 100 \\ \text { Conrad F. Meyer. Silvery rose. } & .75 & 7.50 & \\ \text { Rugosa rubra. Red. } & .60 & 5.75 & \mathbf{4 2 . 0 0} \\ \text { Rugosa alba. White. } & .60 & 6.00 & \mathbf{4 5 . 0 0}\end{array}$

F. J. Grootendorst. A cross of Rosa Rugosa and Baby Rambler. A strong, shrubby grower like tlie Rugosa, which it resembles in foliage as well. 'The flowers are produced in large clusters like the Crimson Baby Rambler. A wonderful rose for individual planting or in masses. 2-year plants, 60c. each; $\$ 6.00$ per doz.

\section{R. HUGONIS}

Golden Rose of China

New hardy single yellow rose, similar to the Persian Yellow. Strong growing shrub. Flowers are very numerous along the stems; distinctly fragrant. Comes into flower about the middle of May. $\$ 1.00$ each; $\$ 10.00$ per doz. 


\title{
HARDY HERBACEOUS PERENNIALS
}

\author{
PRICES \\ Each \\ $\$ 0.30$ \\ 3 of 1 sort \\ .75 \\ 12 of 1 sort \\ 2.50 \\ 100 of 1 sort \\ 18.00 \\ 6 PLANTS AT DOZEN AND \\ 25 PLANTS AT HUNDRED RATE \\ EXCEPT WHERE NOTED.
}

REMEMBER THAT 6 PERENNIALS OF ONE KIND ARE ENTITLED TO THE DOZEN, AND 50 TO

THE HUNDRED RATE.

ACHILLEA

Milfoil, or Yarrow

The Pearl. Pure white, double flowers all summer. Prized for cutting.

ACONITUM

Autumnale

Blue

Monkshood

Fischeri-Azure Monkshood

Napellus

Blue

Sept.

3 it.

.35

AJUGA

Reptans Rubra. Deep purplish blue flowers. Grows 3 to 4 inches high.

\section{ALYSSUM}

Rock Madwort

Saxatile compactum. Broad masses of bright yellow flowers in early spring. An excellent plant for the rockery or front of borders.

ANEMONIE

Alba

Hupehensis

Queen Charlotte

Prince Henry

Whirlwind

ANCHUSA

Italica

AQUILEGIA

Alba

California Hybrids

Coerulea

Nivea Grandiflora

ARABIS

Alpina

ARMERIA

White

Windflower

Pink

Double Pink

Deep Pink

Double White

Rich Blue

White

All colors

Blue

White

White Aug. \& Sept. $2 \mathrm{ft}$. Sept. \& Oct. $2 \mathrm{ft}$. Sept. \& Oct. $2 \mathrm{ft}$. Sept. \& Oct. $\quad 2 \mathrm{ft}$. Sept. \& Oct. $2 \mathrm{ft}$.

Alcanet July 4. $\mathrm{ft}$.

Maritima (Thrift or Cushion Pink). 3 to 6 inch May and June. Valuable for edging; flowers fine purple; foliage grass-like, evergreen. 
-alba. 3 to 6 inches. May and June. Tufts of deep green foliage; white flowers.

\section{ARTEMESIA}

Lactiflora. A tall growing plant of fine foliage and heads of small white flowers in August and september, which fill the garden with fragrance.

\section{ASCLEPIAS}

Butterfly Weed

Tuberosa. Very attractive native plants, flowering during July and August, and growing about $2 \frac{1}{2}$ feet high. Unbels of bright orange colored flowers.

\section{ASTER}

Michaelmas Daisy

Albertross. Pure white.

Beauty of Parfait.

Beauty of Colwell. Double lavender.

Big Bear. Briliant violet.

Climax. Light blueish lavender.

Elta. New, double flowers of pale lilac, very handsome shade. Holland.

Joan Vaughan. Large, semi-double flowers of deepest blue. Many varieties in White, Blue, Pink, and Lavender.

\section{Sept. and Oct.}

Lady Lloyd. A very fine, clear rose-pink.

Leavis Florabunda. Simple blue.

Maggie Perry. Large flowers of soft mauve. Excellent.

Mauve Queen. Very large, semi-double flowers of clear mauve. 4 feet.

Mrs. Raynor. Deepest red of all asters.

Nancy Ballerd. Deep purplish mauve flowers, semi-double in form; flower heads are branched, completely covered with inasses of bloom.

Peggy Ballard. Large, pyramidal sprays of double rosy mauve Howers. 3 feet.

Peter White. Large flowers.

Robinson V. C. A pretty bluish mauve, double flowers borne in long sprays.

Special White.

St. Edgwin. Bright Pink.

Tartaricus. Blueish violet.

\section{ASTILBE}

Japonica. White flowers on long stems.

BOLTONIA

$\begin{array}{llcr}\text { Asteroides } & \text { White } & \text { Summer \& Fall } & 5-7 \mathrm{ft} . \\ \text { Latisquama } & \text { Pink } & \text { Aug. \& Sept. } & 4-5 \mathrm{ft} .\end{array}$

BUDDLEIA

Butterfly Bush

This is properly a shrub, but the top usually freezes back, and new growth starts from the root like other perennials. Plants grow three to four feet and are covered with long racemes of lilac-like flowers in July.

Carpatica (Carpathian Harebell). A pretty species growing in 
compact tufts, not exceeding 8 inches high; flowers clear blue, held erect on wiry stems. It begins blooming in June, continuing until October.

Carpatica alba. A pure white form of the preceding.

Persicifolia grandiflora. (White.) One of the finest Campanulas, with large handsome white bell-shaped flowers.

Persicifolia grandiflora. (Blue.) Companion to the white variety. Large bright blue flowers.

Rotundifolia (Blue Bells of Scotland or Harebells). 1 foot. June to August. Clear blue flowers.

Cup and Saucer Varieties (Campanula calycanthema). Large semi-double flowers, each resenbling a cup and saucer. White, Pink, and Blue shades.

Single Canterbury Bells (Campanula medium).

Pink. Beautiful rich shade.

Blue Light blue flowers.

White. Large white flowers.

CENTAUREA

Montana
Mountain-bluet

\section{CERASTIUM (Snow-in-Summer).}

Tomentosum. A low-growing plant having silvery white foliage and producing an abundance of snow-white flowers. Especially suitable for rock or border purposes.

\section{CHELONE}

Turtlehead

Lyonii. A pretty perennial growing 2 feet tall and bearing snapdragon-like flowers.

\section{CHRYSANTHEMUMS}

Hardy Garden Varieties

Alice Howell. Orange Yellow. Early.

Border Beauty. Orange petals tipped with gold.

Brown Bessie. Pompom. Reddish bronze.

Carrie. Light yellow.

Etoile de Or. Bright yellow. Large.

Excelsior. Bright golden yellow.

Glory of Seven Oaks. Golden yellow.

Golden Queen. Bright yellow.

Jack Bannister. Lemon yellow shaded copper.

L'Argentuillais. Deep chestnut. Early.

Little Barbe. Clear canary yellow.

Model. Light yellow pompom.

Marie Antoinette. Rose pink. Large.

Mrs. F. Collier. Small white.

Niza. Deep pink pompom. Earliest of pinks. Dwarf.

Normandie. White, tinted blush-pink, the earliest of all.

Oconto. Japanese. Large white. October 15.

Old Homestead. Large pink.

Orea. Large shell pink, shading light.

Skibo. Golden yellow. Pompom. October 20.

Snow Clad. Pure white. 
English Single Hybrids. V'ariety of colors.

Well's Scarlet. 'T'erra cotta red.

\section{COREOPSIS}

Lanceolata. Golden yellow. Flower's from June to frost time. DELPHINIUMS

Larkspur

Delphiniums are the most beautiful hardy plants in cultivation, for they have such an immense variety of beauty and increase in size, in beauty, and often in quantity, year after year.

Belladonna. Light sky blue.

Bellamosa. A dark blue of the type of Belladonna.

Choice Mixed English Hybrids. From seea of famous named sorts.

Chinense. A very pretty variety, with fine feathery foliage and intense gentian blue flowers in open panicles.

Chinense album. A pure white form of the above.

DESMODIUM

Sweet Pea Shrub

Penduliflorum. An exceedingly graceful shrub-like plant covered with purplish-red flowers in summer time when little else is in bloom. Strikingly beautiful.

.60 each $6.00 \mathrm{doz}$.

\section{DIANTHUS}

Hybrid Garden Pinks

Without the spicy fragrance of the Hardy Pinks a garden is incomplete. Their perfect form and rich coloring make them great favorites for summer bouquets. June.

Deltoides (Maiden Pink). A beautiful little plant with narrow leaves and bearing a profusion of small, crimson flowers during June and July. Easily grown on rockery.

\section{DICTAMNUS}

Gas Plant

The Dictamnus is one of the most satisfactory hardy plants in cultivation, both on account of splendid flowers and its rich, durable foliage.

Fraxinella rubra.

Fraxinella alba.

.50 each $5.00 \mathrm{doz}$.

.50 each $5.00 \mathrm{doz}$.

\section{DIELYTRA, OR DICENTRA}

A hardy perennial with heart-shaped, rose-colored flowers in drooping spikes.

Spectabilis (Bleeding Heart, or Seal Flower). An old-fashioned favorite; its long racemes of graceful heart-shaped pink flowers are always attractive.

\section{DIGITALIS} .50 each $5.00 \mathrm{doz}$.

Foxglove

The flower-heads are over 3 feet long, crowded with big, bellshaped blossoms. Colors range from white and shell-pink to deepest rose, many attractively dotted with crimson or chocolate.

\section{DORONICUM}

Leopardbane

Caucasicum. Large bright yellow flowers; one of the most effective early Spring flowering perennials. Effective as a single plant, or in a hardy border. It is a splendid flower for cutting.

\section{FUNKIA}

Lancifolia. Laceleaf Plantain Lily.

Media Picta. Variegated leaf, used extensively as a border plant.

Subcordata. Old fashioned Day Iily. $\quad .35$ each 4.00 doz. 
GAILARDIA

Blanket Flower

Grandiflora. June to frost. Center dark red-brown, petals crimson-orange and vermilion.

GYPSOPHILA

Baby's Breath

Desirable where a mass of delicate misty bloom will fill in a bare place.

\section{HELIANTHUS}

Double Hardy Sunflower

Maximiliani. The latest of all. Golden yellow flowers in graceful sprays in October. Fine for cutting. 6 feet.

Multiflorus. Large, double Dahlia-like golden-yellow flowers in great profusion July and August; 4 feet.

\section{HELIOPSIS}

Orange Sunflower

Pitcheriana. A desirable variety. The flowers are of a beautiful deep golden-yellow, about two inches in diameter, of very thick texture and a useful cut flower.

\section{HELENIUM}

Sneezewort

Autumnale superbum. Broad heads of deep golden-yellow flowers in late summer. Grows 5 to $6 \mathrm{ft}$. high.

Autumnale rubrum. A splendid new variety; deep ox-blood red, changing to terra-cotta. 5 to 6 feet. September.

Riverton Gem. New. Old gold, suffused with bright terracotta, changing to wallflower-red. August to October.

\section{HEMEROCALLIS}

\section{Yellow Day Lily}

Lemon Lilies, or Hemerocallis, have long been favorites in our garden, and are always included in any list of the most popular hardy plants.

Flava (Lemon Lily). Sweet-scented, clear full yellow. $2 \frac{1}{2}$ feet. Flowers in June.

Thunbergi. Much like Flava, but flowers in July, a month later.

Fulva. (Brown Day Lily.) July. Copper orange, shaded crimson.

\section{HEUCHERA}

Allum Root

Dwarf, compact, bushy plants of easy culture, growing $1 \frac{1}{2}$ to 2 feet high.

\section{HIBISCUS}

Mallow, or Crimson Eye

Colors assorted. Pink, red and white.

\section{HOLLYHOCKS}

Althea Rosea

Old garden farorites. One of the most stately, picturesque and beautiful plants in the world.

Double. Separate colors, red, maroon, white, yellow, pink, Newport pink, white with purple base, bright rose.

Single. Red, white, pink mixed.

\section{IBERIS}

Hardy Candytuft

Gibraltarica Hybrida. White, shading to lilac.

Sempervirens. A profuse, white-blooming, hardy perennial, coming in flower early in the spring; much used for cemeteries, rockeries, etc.; 1 foot. 
IRIS, GERMAN

Germanica

One of the most popular hardy spring flowering plants.

Caprice. Chinese Violet.

Fairy. White suffused blue.

Florentine alba. Producing large fragrant white flowers.

James Boyd. Blue and violet.

Japanesque. Lavender and white.

Khedive. Soft lavender, orange beard.

Kochi. Dark purple.

Lorelei. Falls marine-blue veined with white and bordered with yellow.

Madam Chereau. White feathered edges of sky blue; free flowering.

Mamie. White, edged light blue.

Monsignor. Deep purplish blue.

Mrs. Allen Gray. Rose mauve.

Mrs. H. Darwin. White and lavender.

Niblungen. Fawn yellow, falls blue.

Nine Wells. Violet and blue.

Pocohontas. White, penciled lavender, nearly double.

Powhatan. Violet purple.

Queen of May. A lovely soft rose-lilac, almost pink; a very beautiful shade.

Rose Unique. Early pink.

Rhine Nix. White and blue.

San Souci. Golden yellow.

Seminole. Violet rose and crimson.

Sea Gull. Blue and white.

Sherwin Wright. Golden yellow.

IRIS, JAPANESE

Iris Kaempferi

35 cents each: $\$ 3.50$ per dozen. Double, except where noted.

Celia. Pink, spotted and sprinkled.

Gekka-No-Nami. Creamy white.

Gold Bound. Pure white; yellow markings.

Harris No.71. V'ery dark bluish, large bright yellow halo.

Hano No Mio. Mahogany red.

Helen-Van-Seibolt. Reddish, veined white.

Isso-No-Nami. Rosy lilac, rose center.

Komata. Sky blue, veined and splashed white.

Koko-No-Obi. Clear purple white, purple tipped.

Kuma-Funjin. A very tall double, purple, veined white, yellow center.

Kuma-Chi-Guma. Dark Bluish purple.

Mt. Hood. Light blue, shaded darker.

Neptune. Single, mahogany red.

Norma. Deep purple.

Old Rose. Dark shade of old rose.

Oniga-Shima. Brilliant violet-purple with golden center. One of the best. 
Peacock. Violet purple, veined with white; large.

Prince C. de Rohan. Deepest dark purple.

Purple \& Gold. Violet purple.

Seco-No-Nami. Single, reddish purple, splashed white, early.

Shufu-Ruku. Pinkish showy colorings.

Shoko-No-Nishiki. Lilac on white.

Vase-Banri. White, veined blue.

Yedo-Jaman. Royal Blue.

Vera. 'This is the true Sweet Lavender; grows about 18 inches high; delightfully fragrant blue flowers in July and Augusi.

\section{LIATRIS}

Blazing Star, or Gay Feather

Showy and attractive native plants, succeeding anywhere, producing large spikes of flowers from July to September.

Pycnostachya. Spikes of light, rosy-purple flowers. 5 feet

\section{LOBELIA}

Cardinalis. Long, dense spikes of handsome rich cardinal- $r \mathrm{~d}$ flowers.

\section{LUPINUS}

Polyphyllus (Lupin). Deep blue pea-shaped flowers on lorig spikes. June to September. 2 to 3 feet.

Polyphyllus albus. Pure white.

\section{LYCHNIS}

Chalcedonica (London Pride). Brilliant scarlet flowers in close heads. June to September.

Viscaria splendens fl. pl. Bright rose flowers in spikes.

\section{LILIES}

Lilium

Lily-of-the-Valley.

Auratum. Gold banded.

Candidum (Annunciation Lily). A most beautiful and well known fragrant lily. Clear white. 50c. each; $\$ 5.00$ doz.

Lancifolium rubrum. White, shaded with rose and spotted with red.

50c. each; $\$ 5.00 \mathrm{doz}$.

Regale. A new variety from Western China. One of the most beautiful Garden Lilies yet introduced. 'The large trumpetshaped, delicately scented flowers, which are produced freely, are ivory white, shaded pink, tinged with canary-yellow at the base of the petals. Strong flowering bulbs. $75 \mathrm{c}$. each; $\$ 7.50$ doz.

Speciosum album. Pure white, with a slight tinge of rose on end of petals; one of the best. 50c. each; $\$ 5.00$ per doz.

Tigrinum splendens. Bright orange-scarlet, with dark spots. 20c. each; $\$ 2.00$ doz.

MONARDA

Bergamot

Showy plants growing from 2 to 3 feet high, succeeding in any soil or position, with aromatic foliage, and producing their bright flowers during July and August.

Didyma. Brilliant crimson-scarlet. 
MYOSOTIS

Palustris Semperflorens. A variety that is hardly ever out of flower; useful in a shady spot in the border.

Hybrids. Pink shades.

\section{PAEONIES}

Strong roots containing three or more eyes. 50c. each; $\$ 5.00$ per doz. except as noted.

Artemise. Salmon pink, crown type.

Ambrose Verschaffelt. Red.

B. Rosthchild. Petals light pink, center creamy white.

Baroness Schroeder. Flesh color, changing quickly to white; creamy center.

$\$ 2.00$.

Duc De Wellington (Calot, 1859). 7.8. Bomb type. Large flower of good form. White guard petals with sulphur center.

Felix Crousse. Brilliant red with flame center.

$\$ 1.00$.

Festive Maxima. Pure, waxy white with occasional flecks of crimson on the central petals. The most popular Peony in existence.

$75 \mathrm{c}$.

Francois Ortegat. Dark crimson.

Grandiflora Rosea. Rosy pink.

Mons. Jules Elie. Medium pink.

Officinalis Rubra. Dark red; fragrant. Very early. $\$ 1.00$

Pres. Roosevelt. Brilliant dark crimson. $75 \mathrm{c}$. each.

Prince Charles. Pink.

Primavere. Creamy yellow.

$\$ 1.50$ each

Roem Van Boskoop. Flesh white.

Richardson's Grandiflora. Double pink. $\quad \$ 1.00$ each

Rubra Triumphans. Dark red. $\$ 1.00$ each

Rubra Superba. Deep crimson. $\$ 1.00$ each

PAPAVIA

Poppies

Orientale. The common variety of Oriental Poppy. The flowers are a bright scarlet with a black blotch at the base of each petal, and when in bloom in the spring they make a very brilliant display.

Iceland. A beautiful species and among the most desirable of our herbaceous plants.

\section{PENTSTEMON}

Beard Tongue

Barbatus Torreyii. Scarlet.

Digitalis. Purple white.

Pubescens. Bright rosy-purple. 11/2 feet.

\section{PHLOXES}

The hardy Phloxes are without doubt among the most important of all hardy perennials, and are now to be found in almost every garden. They succeed in almost any kind of soil and position, and flower from early summer until late in the fall; they also improve from year to year, and contain a range of brilliant colors not found in any other hardy plant. 
Alpha. New variety from France. Brilliant rosy pink, long trusses.

Annie Cook. Flesh pink.

Astrild. Clear large red.

B. Comte. French purple.

Dantons. Light madder, maroon eye.

Deutschland. A rich scarlet variety.

Elizabeth Campbell. Large spikes of bright salmon flowers, changing to pink in center.

$35 \mathrm{c}$.

Enchantress. Salmon pink. Much better than E. Campbell.

Europa. White; decided crimson eye.

Fiancee. Pure white.

Frau Antoine Buchner. Largest pure white.

Jean D'Arc. Pure white; late.

Johnson's Favorite. Light salmon-pink. Red eye. Better than E. Campbell.

Le Caid. Pink; darker eye.

Lord Raleigh. Purple, white markings.

Maid Marion. New variety. Soft lavender large flower, profuse bloomer.

Mrs. Lingard. White flowers with pale pink center. Early.

Mrs. Jenkins. Beautiful clear white.

Mrs. Scholton. Salmon-scarlet.

Pantheon. Brilliant rose, very effective.

Peach Blow. Pale pink, shading lighter toward edge.

R. B. Struthers. Bright, pinkish salmon, crimson eye.

Rheinlander. Beautiful salmon-pink.

Rynstrom. Color of Paul Neyron rose; very large.

Selma. Pale lavender.

Sir Edwin Landseer. Flowers bright crimson.

Special French. Beautiful clear pink.

Thor. Deep salmon-pink.

Wanadis. White with lilac stripes. Very distinct purple eye. Somewhat resembles Phlox Divaricata Canadensis.

W. C. Egan. Delicate lilac with reddish eye.

\section{PHLOX SUBULATA}

Moss, or Mountain Pink

An early spring-flowering type, with pretty moss-like evergreen foliage, which, during the flowering season, is hidden under the masses of bloom. An excellent plant for the rockery, the border, and invaluable for carpeting the ground or covering graves.

Alba. Pure white.

Atropurpurea. Purplish-rose.

\section{PHYSOSTEGIA}

False Dragon-Head

One of the most beautiful of our mid-summer flowering perennials, forming dense bushes 3 to 5 feet high, bearing spikes of delicate tubular flowers not unlike a gigantic heather.

Virginica. Bright but soft pink.

Virginica alba. Pure white; very fine. 
PLATYCODON

Balloon Flower, or Japanese Bell-Flower

Grandiflorum. Deep blue cupped, star'-shaped flowers

Grandiflorum album. A white-flowered form of the above.

Mariesi. Deep blue bell-shaped flowers, nearly 3 inches across. PRIMROSES

Veris (Invincible Giant). Yellow. June and July. 18 inches. Japonica. White, Lilac, Bright Rose, Deep Pink. June and July. 18-24, inches.

\section{PYRETHRUM}

Persian Daisy

Hybridum. Red, Pink, Lavender, Yellow. June. 3-4 feet.

\section{ULIGINOSUM}

Giant Daisy

Grows 3 to 4 feet high and is covered with large white Daisylike flowers, 3 inches in diameter, from July to September.

PINKS, Hardy Garden

(See Dianthus).

\section{RUDBECKIA}

Coneflower

Golden Glow. One of the most popular hardy plants. Grows six feet high, producing masses of large, double, goldenyellow flowers.

\section{SAPONARIA}

Soap Wort

Ocymoides Splendens. A very useful plant for the rockery or the border, producing from May to August, masses of attractive small bright rose flowers; 8 inches.

Rose Queen. Bright rose color.

SCABIOSA

Blue Bonnet

Caucasica. A soft and charming shade of lavender. June to September.

\section{SEDUM}

Stonecrop

Spectabilis. Rose. Late summer and fall.

Spectabile "Brilliant." A rich colored form of the preceding, being a bright amaranth-red.

\section{SIDALCEA}

Erect growing branching plants 2 to 3 feet high, producing during June and July pretty, mallow-like flowers, about an inch in diameter.

Rose Queen. Bright rose color.

SPIREA (Astilbe)

Betsy Cuperius. Tall, new variety with drooping flower spikes 2 feet long. White flowers with pink center. .50 each.

Brunhilde. Thick flower spikes crowded with clear lilac flowers. .50 each.

Ceres. Growing $2 \frac{1}{2}$ feet to 3 feet high, with spikes of a rosy lilac color. A fine garden variety. .50 each.

Freule Van Den Bosch. New variety, growing about $3 \frac{1}{2}$ feet high. Produces compact flower spikes of a dark pink color.

.75 each.

Grandis Rosea Maxima. The drooping spikes of flowers have a length of over 2 feet, and are a beautiful creamy white with pink centers. 5 to 6 feet. 
Marguerite Van Rechteren. This plant grows about 5 feet high. The flower stem has a length of over 3 feet. The very fine fringed flowers are bright red tinged with dark lilac.

.50 each.

Meta Immink. Splendid new cross having dense flower spikes of a delightful pink color. Very recommendable. Award of merit R. H. S. of Holland.

.50 each.

Prof. V. D. Wielen. New, with gigantic long stems and side stems, showing fine small, pure white flower's in profusion.

.75 each.

Salland. Stems of a fine red color, growing over 6 feet high. A very decorative novelty. Award of merit R. H. S. of liulland.

.75 each.

Vesta. New. Tall, lilac-rose spikes; beautiful garclen variety.

\section{SPIREA}

$\$ 1.00$ each.

Filipendula. Numerous corymbs of white flowers on stems 15 inches high, during June and $\mathrm{July}$, and pretty fern-like foliage.

\section{SHASTA DAISIES}

Large snowy-white flowers, in bloom continuously throughout the entire summer and fall.

SWEET WILLIAM

Assorted. Crimson, Scarlet, White, Pink, etc. June.

STOKESIA CYANEA

Cornflower Aster

Caerulea. Beautiful light blue.

Alba. White-flowered form of above. 1 foot to 18 inches.

TRITOMA

Red-hot Pokex

Pfitzeriana. Orange-scarlet. August to Uctober. 3 feet.

TROLLIUS

Globe Flower

Europæus. Large, bright yellow, globular flowers.

VALERIANA

Spurred Flower

Officinalis (Hardy Garden Heliotrope). Produces showy heads of rose tinted white flowers during June and July, with strong heliotrope odor.

\section{VERONICA}

Speedwell

The Speedwells are mostly natives of New Zealand, flowers being of a blue shade, varying to rose and dull white. 'Ihey succeed in any garden soil in sunny situations. 'The low-growing forms are good rock plants.

Longifolia subsessilis. A pretty species with blue flowers produced on spikes 1 to $1 \frac{1}{2}$ feet long, continuing in bloom the entire summer.

Spicata. Fine border plant, about 18 inches high, producing spikes of bright blue flowers in summer.

\section{VIOLAS}

Tufted Pansies

They flower continuously for nearly eight months in the year.

Blue Perfection. Deep purplish blue.

Lutea Splendens. Rich golden yellow.

Papilio. Violet, with dark eye; the most effective for massing.

White Perfection. A fine white. 


\section{FRUIT DEPARTMENT}

APPLES, Standard
6 to $7 \mathrm{ft}$.
Each
Per 10
1.00
8.00

Ask for special prices for 100 or more.

Varieties:

Early

*Astrachan-Red

* Early Harvest-Yellow

* Golden Sweet-Yellow

* Sweet Bough-Yellow

William's Favorite-

Red and white

* Yellow Transparent-Yellow

Mid-Season

* Duchess of Oldenburg -

* Fall Pippin-Yellow

\section{Striped}

* Liravenstein-Striped

Fameuse-Red

*McIntosh Red-Red

* l'urter

* Wealthy-Striped

Cortland (New Variety Developed by New York State Experimental station.) A fine apple resulting from the cross pollization of McIntosh and Ben Davis. Inheriting only the good qualities of each. The Cortland is a beautiful red apple, larger than the McIntosh, of better quality and matures a month later. Keeps late in winter and can be handled and shipped like the hardiest of other market varieties.

APPLES, Dwarf, on Doucin Stock. Varieties marked *

\begin{tabular}{|c|c|}
\hline 5 to $6 \mathrm{ft}$. & 1.00 \\
\hline 4 to $5 \mathrm{ft}^{\circ}$ & .90 \\
\hline 3 to $4 \mathrm{ft}$. & .60 \\
\hline
\end{tabular}

APPLES, Crab
6 to $7 \mathrm{ft}$.
1.00
5 to $6 \mathrm{ft}$.

Varieties:

Hyslop-Red

'Transcendent-Striped

\section{CHERRIES}
6 to $7 \mathrm{ft}$.
1.50
13.50

Varieties:

\section{Sweet}

\section{Sour}

Early Richmond-Red

Bigarreau-Black

Black Tartarian-Black

Gov. Wood-Red on white

Windsur-Dark

Yellow Spanish-White
May Duke-Red

Montmorency-Red

Morello-Red 
PEAR TREES, Standard

$\begin{array}{llll}6 & \text { Each } & \text { Per } 10 & \text { Per } 100 \\ 5 \text { to } 7 \mathrm{ft} . & 1.50 & 13.50 & \end{array}$

Varieties:

*Anjou-Winter

* Bartlett-Summer

*Clapp's Favorite-Summer

*Duchess-Fall

Lawrence-Winter

* Seckel-Fall

Sheldon-Fall

Vermont Beauty-Summer

Wilder-Summer

Worden Seckel-Fall

PEARS, Standard

Varieties :
5 to $6 \mathrm{ft}$.
1.50
13.50

Beurre Bosc

Winter Nellis

PEARS, Dwarf. Varieties marked * above
4 to $5 \mathrm{ft}$.
1.00
9.00
3 to $4 \mathrm{ft}$.
.75
7.00

\section{PEACHES}

4 to $6 \mathrm{ft}$.

.60

5.00

41).00

Varieties: In the orler of their ripening.

Mayflower

Greensboro

Waddell

Carman

Mountain Rose

Champion

Crawford Early

Belle of Georgia

Old Mixon

Elberta

J. H. Hale

Crawford Late
-Red

-White with red cheek

-White and blush

-White with red cheek

-White and Red

-White and Red

-Yellow

-White with red cheek

-White with red cheek

-Yellow

-Yellow

-Yellow

PLUMS
6 to $7 \mathrm{ft}$.
5 to $6 \mathrm{ft}$.
1.25
11.00
1.00
9.00

Varieties: In the order of their ripening.

Japanese

Red June-Red

Abundance-Red

Burbank-Red

Wickson-Red

Bradshaw-Blue

\section{European}

Lombard-Purple

Damson-Blue

Beauty of Naples-Yellow

German Prune-Blue

\section{QUINCES}

$\begin{array}{rrr}4 \text { to } 5 \mathrm{ft} . & 1.00 & 9.00 \\ 3 \text { to } 4 \mathrm{ft} & .75 & 7.00\end{array}$

Varieties:

Borgeat

Champion 
GRAPE VINES

2 year

.50

4.00

Varieties:

Agawam-Red

Delaware-Red

Brighton-Red

Diamond-White

Caco-The New Red Grape without a Fault. $\$ 1.00$ each. Concord-Black

Moore's Early-Black

Niagara-White

Worden-Black

\section{GRAPE VINES}

Varieties:

2 year

Campbell's Earlv-Black

Eaton-Black

Each

Per 10 Per 100

.60

5.00

Green Mountain-White

\section{SMALL FRUIT STOCK}

RASPBERRIES, Red and Black

Varieties:

Red

Cuthbert

Golden Queen (Yellow)

Herbert

Latham

St. Regis

RASPBERRIES, Columbian (Purple)
.15

1.00

6.00
Black Cap

Gregg

La France.-New Everbearing Giant Red Raspberry.

$$
.25 \quad 2.50
$$

BLACKBERRIES

Varieties :

.10

1.00

Eldorado

Mercereau

Rathburn

Snyder

\section{RHUBARB}

\section{.25 \\ 2.60}

ASPARAGUS, CONOVERS-PALMETTO

2 year ( $\$ 16.00$ per 1000$)$

A. WASHINGTON

A new variety of great merit, superior in every way to the older sorts.

1 year $(\$ 16.00$ per 1000$)$

2 year $(\$ 25.00$ per 1000$)$

.35

2.00

.50

$3 .(11)$ 


\section{STRAWBERRIES}

Everybody's favorite fruit, and so prolific that a few rows across the garden will supply the family with the most delicious berries, so superior to those bought in the market that there is no comparison. Plant 18 inches apart in the row and space the rows three to four feet apart.

This spring we supply strong runner plants at the prices quoted. In the late autumn we can furnish potgrown plants of the following varieties at a uniform price of $\$ 2.50$ for 25 , or $\$ 6$ per 100 .

Aroma. Large, blocky, bright red fruits of mild flavor and high quality. Good for home and market, 75 cents for $25, \$ 2.50$ per 100 .

Marshall. A large, midseason berry of handsome appearance and rich flavor. Dependably productive, 75 cents for $25, \$ 2.50$ per 100 .

Progressive. A splendid autumn-fruiting sort. It bears well throughout the season, but it is best to keep the blossoms picked off until fall in order to enjoy the splendid crops it will produce then. $\$ 1$ for 25 , $\$ 3$ per 100.

Senator Dunlap. Handsome fruits of great excellence for home or market. A midseason sort which is highly regarded by all who know it. 75 cents for $25, \$ 2.50$ per 100 .

Howard's No. 17-One of the best all-round berries. 


\section{INDEX TO DEPARTMENTS}

\begin{tabular}{|c|c|c|c|}
\hline Deciduous Trees & . & & . \\
\hline Evergreen Trees & . & & . \\
\hline Evergreen Shrubs & - & & . \\
\hline Hedge Plants & . & & . \\
\hline Deciduous Shrubs & . & & , \\
\hline Climbing Vines & . & 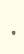 & \\
\hline Roses & . & & \\
\hline Hardy Herbaceous & Perennials & & \\
\hline Fruit Department & . & . & \\
\hline
\end{tabular}



